\title{
Ceza Muhakemesinde Hakim ve Mahkeme Kararlarının İlgilisine Bildirilmesi
}

\author{
Notification the Relevant Persons of the Judge's or Court's Decisions in \\ Criminal Procedure
}

Faruk Turhan ${ }^{*}$

\section{öz}

Hakim ve mahkeme kararlarının önemine binaen bu kararların ilgilisine bildirilmesi Ceza Muhakemesi Kanunu md. 35'te özel olarak düzenlenmiştir. Bu temel düzenlemeye göre, mahkeme ve hakim kararlarının ilgilisine bildirilmesi esas itibariyle üç şekilde söz konusu olmaktadır: İlgili tarafın yüzüne karşı verilen kararlar kendisine açıklanarak bildirilecektir. Eğer kararın verildiği sırada ilgili taraf hazır değilse karar kendisine tebliğ edilerek bildirilecektir. Kararın verildiği sırada hazır olmayan kişi serbest olmayan bir kişi veya tutuklu ise karar, hem tebliğ edilerek hem de okunup anlatılarak bildirilecektir. Çalışmada, bu bildirim şekillerinin kapsam ve koşuları ile bildirime ilişkin diğer hususlar kaynak Alman Kanunu ve doktrindeki görüşler ışığında eleştirel bir bakış açısıyla incelenmiştir. Ayrıca Cumhuriyet başsavcılığına tebligatın nasıl yapılacağı ve Tebligat Kanunu karşısında Ceza Muhakemesi Kanununun tebligata ilişkin hükümlerinin uygulanabilirliği konuları da çalışma kapsamında ele alınmaktadır.

Anahtar Kelimeler: Hakim ve Mahkeme Kararlarını Bildirilmesi, İnfazı Gereken Kararlar, Hukuki Dinlenilme Hakkı, Cumhuriyet Başsavcılığına Tebligat, İnfazı Gereken Kararların Başsavcılığa Verilmesi, Ceza Muhakemesinde Elektronik İșlemler

\section{ABSTRACT}

Due to the importance of judge and court decisions, notification of these decisions to the person concerned is specifically regulated in Code of Criminal Procedure Article 35 and the following articles. According to this provision, notification of court and judge decisions to the person concerned is basically in three ways: Decisions made against the face of the relevant party will be announced and notified to him/her. If the relevant party is not ready at the time of the decision, the decision will be serve upon to him/her. If the person who was not present at the time of the decision is a person who is not released or under arrest, the decision will be notified both by notification and by reading and explaining. In the study, the scope and conditions of these notification forms and other issues related to notification are examined with a critical perspective in the light of the views in the source German law and doctrine. In addition, the subject of the procedure for the notification to be made to the Office of the Chief Public Prosecutor and the applicability of the provisions of the Criminal Procedure Code against the Notification Law are also examined within the scope of the study.

Keywords: Notification of Judge and Court Decisions, Decisions to be Executed, Right to be Heard, Notification to the Office of the Chief Public Prosecutor, Submission of Decisions to be Executed to the Office of the Chief Prosecutor, Electronic Processes in Criminal Procedure Law

* $\quad$ Prof. Dr., Süleyman Demirel Üniversitesi Hukuk Fakültesi Ceza ve Ceza Muhakemesi Hukuku Anabilim Dalı, ORCID ID: 0000-0002-4250-4675.

Sorumlu Yazar/Correspondence Author: Faruk Turhan E-posta/E-mail: farukturhan@sdu.edu.tr 


\section{GíRiş}

Hakimler ve mahkemelerce verilen kararların sonuç doğurabilmeleri için kural olarak ilgilisine bildirilmesi ve bu bildirimin de mevzuatta belirtilen usule uygun olarak yapılması gerekir. Çünkü bu kararlardan doğan hakların kullanılabilmesi işlemden haberdar olma ile mümkündür. ${ }^{1}$ Özellikle kararlara karşı kanun yoluna başvurma imkanının olup olmadığının bilinmesi ve devam eden muhakeme sürecinde nasıl bir yol izleyeceğinin değerlendirilebilmesi için kararların ilgilisine bildirilmesi gerekir.

Kararların ilgili kişilere bildirilmesi ise ya doğrudan doğruya bildirme ya da dolaylı bildirme şeklinde olur. Doğrudan doğruya bildirmede, kararı veren kişi ya da makam araya herhangi bir vasıta koymaksızın işlemi doğrudan ilgiliye bildirmektedir. Bu bildirime tefhim denilmektedir. ${ }^{2}$ Bildirilecek yazılı belgenin ilgiliye elden verilmesi (Tebligat Kanunu (TK) md. 36), celse esnasında avukat katip ve stajyerlerine bir sonraki celse ve gün saatinin bildirilmesi bildirilmesi (TK md. 37) halinde de doğrudan doğruya bildirme söz konusudur. ${ }^{3}$ Dolaylı ya da vasıtalı bildirmede ise işlemi yapan kişi ya da makam araya bir vasıta koyarak işlemi ilgilisine bildirmektedir. Bu şekildeki bildirmeler tebliğ olarak adlandırılmaktadır. ${ }^{4}$ Tebliğ, bildirimin dolaylı şekli olduğu için bütün bildirimleri ifade etmek üzere kullanılması yerinde değildir. ${ }^{5}$ Teknolojik gelişmelerin ceza muhakemesinde yoğun olarak kullanılması ile birlikte bildirimlerin elektronik yollarla yapılması usulü de kabul edilmiştir. Elektronik ortamda yapılan tebligat da dolaylı bildirimin yeni bir şeklidir. ${ }^{6}$

Ceza muhakemesi işlemlerinin ilgilisine bildirilmesine ilişkin, Ceza Muhakemesi Kanunu (CMK) ve TK'da çeşitli düzenlemelere yer verilmiştir. Ceza muhakemesinin en önemli muhakeme işlemlerinden olan hakim ve mahkeme kararlarının ilgilisine bildirilmesine ilişkin temel düzenlemeler CMK’nın İkinci Kısım, Birinci Bölümü altında yer alan md. 35-38'de yapılmıştır. Bu maddeler dışında, tutuklama kararının şüpheli veya sanığa bildirilmesi (md. 101/2), tutuklunun yabancı olması halinde durumunun vatandaşı olduğu konsolosluğuna bildirilmesi (md. 107/3), duruşma gün ve

1 Nur Centel ve Hamide Zafer, Ceza Muhakemesi Hukuku (19. Bası, Beta 2020) 474; Cumhur Şahin ve Neslihan Göktürk, Ceza Muhakemesi Hukuku Cilt II (11. Bası, Seçkin 2021), 240; Ahmet Gökcen, Murat Balc1, M. Emin Alşahin ve Kerim Çakır, Ceza Muhakemesi Hukuku (5. Bası, Adalet 2021) 267; Vahit Bıçak, Ceza Muhakemesi Hukuku (4. Bası, Seçkin 2018) 745 .

2 Feridun Yenisey ve Ayşe Nuhoğlu, Ceza Muhakemesi Hukuku (7. Bası, Seçkin 2019) 130; Centel ve Zafer (n 1) 747 vd; Şahin ve Göktürk (n 1) 241; Yener Ünver ve Hakan Hakeri, Ceza Muhakemesi Hukuku (17. Bası, Adalet 2020) 147; Bahri Öztürk, Durmuş Tezcan, Mustafa Ruhan Erdem, Özge Sırma Gezer, Yasemin F. Saygılar Kırıt, Esra Alan Akcan, Özdem Özaydın, Efser Erden Tütüncü, Derya Altınok Villemin ve Mehmet Can Tok, Nazari ve Uygulamalı Ceza Muhakemesi Hukuku, (13. Bası, Seçkin 2019) 286-287; Nevzat Toroslu ve Metin Feyzioğlu, Ceza Muhakemesi Hukuku (20. Bası, Savaş 2020) 189.

3 Öztürk, Tezcan, Erdem, Gezer, Saygılar Kırıt, Alan Akcan, Özaydın, Tütüncü, Villemin ve Tok (n 2) 286; Veli Özer Özbek, Koray Doğan ve Pınar Bacaksız, Ceza Muhakemesi Hukuku (13. Bası, Seçkin 2020) 136; TK md. 37'de, "Celse esnasında kazai merci tarafindan sıfatları tesbit edilen avukat katiplerine ve stajyerlerine mütaakip celse gün ve saatinin bildirilmesi avukata tebliğ hükmündedir." denilmekte ise de burada usul açısından bir tebliğ değil, doğrudan bildirme söz konusudur.

4 Yenisey ve Nuhoğlu (n 2) 131; Centel ve Zafer (n 1) 748; Öztürk, Tezcan, Erdem, Gezer, Saygılar Kırıt, Alan Akcan, Özaydın, Tütüncü, Villemin ve Tok (n 2) 286; Şahin ve Göktürk (n 1) 241; Ünver ve Hakeri (n 2) 148.

5 Nurullah Kunter, Feridun Yenisey ve Ayşe Nuhoğlu, Ceza Muhakemesi Hukuku (15. Bası, 2006) 519.

6 Centel ve Zafer (n 1) 748. 
saatinin sanığın kanuni temsilcisine bildirilmesi (md. 155/1), iddianamenin sanığa tebliği (md. 176) ve hükmün açıklanmasında (md. 231) olduğu gibi CMK'da, hakim ve mahkeme kararlarının ilgilisine bildirilmesine ilişkin özel düzenlemelere de yer verilmiştir. Diğer taraftan gözaltı süresinin uzatılması emrinin gözaltına alınana derhâl tebliğ edilmesi (md. 91/3), elkoyma işleminin, suçtan zarar gören mağdura gecikmeksizin bildirilmesi (md. 127/5) gibi başka mercilerin yaptığı muhakeme işlemlerinin ilgilisine bildirilmesine ilişkin CMK’nın çeşitli maddelerinde düzenlemelere de yer verilmiştir. Söz konusu bu hükümler md. 35’e göre özel hüküm niteliğinde olduğu için öncelikle uygulama alanı bulacaktır.

Md. 37/1’e göre, CMK'daki özel hükümler saklı kalmak üzere, tebligat işlemleri ilgili kanun hükümlerine göre yapılacaktır. Burada söz konusu olan kanun 7201 sayılı Tebligat Kanunudur.

Kararların bildirilmesine ilişkin CMK’nın 35-38. maddeleri ile ilgili olarak doktrinde şimdiye kadar detaylı bir çalışma yapılmadığı görülmektedir. Halbuki bu düzenlemeler adil yargılanma hakkı açısından önemli olduğu gibi, düzenlemelerden bazıları da sorunludur. Çalışmada söz konusu hükümler kaynak Alman CMK'daki düzenlemeler, doktrin ve Yargıtay kararları ışığında eleştirel bir incelemeye tabi tutulacaktır. Aşağıda önce hakim ve mahkeme kararlarının bildirilmesinin adil yargılanma hakkı açısından önemi, arkasından da CMK md. 35-36’ya göre hakim ve mahkeme kararların ilgilisine bildirilmesi ve 38. madde uyarınca Cumhuriyet başsavcılığına tebligatın yapılması konuları açıklanacak, son olarak da tebligat usulüne ilişkin TK hükümleri karşısında CMK hükümlerinin uygulanabilirliği üzerinde durulacaktır. Tebliğ usullerinin detaylı olarak düzenlendiği TK hükümleri ile CMK’nın diğer maddelerinde yer alan bildirimlere ilişkin düzenlemeler çalışmanın kapsamını genişletmemek için zorunlu olmadıkça ele alınmayacaktır.

\section{KARARLARIN BILDIRILMESININ ADIL YARGILANMA HAKKI ILE íişKISi VE AMACI}

Anayasa ve kanunlarla güvence altına alınan hak arama özgürlügünün kullanılabilmesi için devlet işlemlerinin kişilere usulüne uygun olarak bildirilmesi gerekir. Bu nedenle verildiği oturumda hazır bulunmayan ilgiliye hakim ve mahkeme kararları usulüne göre bildirilmelidir. ${ }^{7}$ Hakim ve mahkeme kararların bildirilmesine ilişkin kanundaki düzenlemeler adil yargılanma hakkı kapsamında yer alan hukuki dinlenilme hakkının sağlanmasına ve güvence altına alınmasına da hizmet etmektedir. ${ }^{8}$

7 "Kişilerin hak arama hürriyetlerinin Anayasa ve diğer kanunlarla güvence altına alındığı ve bu hakkın kullanılabilmesi için devlet işlemlerinin kişilere usulüne uygun olarak bildirilmesi gerektiği, bu bağlamda itiraza konu hükümlerin kurulduğu 19.01.2016 tarihli oturuma katılmayan katılan ... vekilinin yokluğunda verilen kararın katılan vekili Av. ...y tebliğe çıkarıldığı, ancak muhatabın adreste tanınmadığı gerekçesiyle tebligat mazbatasının iade edildiği anlaşıldığından 5271 Sayılı CMK’nın 35 ve 260. maddelerine göre hükümlerin katılan kuruma usulünce tebliğ edilmesi gerekmektedir.”: Yargitay CGK, E 2019/9-355 K 2019/596, 10.10.2019: aksi belirtilmediği sürece Yargitay kararları https://lib.kazanci.com.tr veri tabanından alınmıştır;_aynı yönde bkz. Yargıtay CGK, E 2016/23-1344 K 2020/218, 21.05.2020.

8 Edda Wesslau, StPO $\$ 35$ Kenar no (Kn.) 1, in: Jürgen Wolter (Ed), SK-StPO, Systematischer Kommentar zur Strafprozessordnung mit GVG und EMRK Cilt I, $\$ \S 1-93$ (4. Bası 2013); Heinrich Maul, StPO $\$ 36$ Kn. 10, in: Rolf Hannich (Ed) Karlsruher Kommentar zur Strafprozessordnung mti GVG, EGGVG und EMRK (8. Bası 2019). 
Alman hukukunda “das Recht auf rehtliches Gehör” olarak ifade edilen hukuki dinlenilme hakkı ${ }^{9}$ için Türk hukukunda farklı ifadeler kullanılmakla birlikte ceza muhakemesi hukukuna ilişkin yayınlarda genellikle meramını anlatma veya anlatabilme terimi kullanılmaktadır. Meramını anlatabilme, kişinin söylemek istediklerini anlatabilmesi hakkını ortaya koymakla birlikte, hukuki dinlenilme hakkının kapsamına giren bütün hakları ifade etmekte yeterli olmadığı için doktrinde hukuki dinlenilme hakkı terimi tercih edilmektedir. ${ }^{10}$ Çünkü hukuki dinlenilme hakkı sadece muhakemeye katılanların tek taraflı olarak meramını anlatabilmesi imkanı değil, ayrıca ilgili merciin yapılan açıklamayı dikkate alması ve kararlar hakkında bilgilendirilme ve kararın ilgilisine bildirilmesi yükümlülüğünü de içermektedir. ${ }^{11}$

Hukuki dinlenilme hakkı AİHS'de açıkça düzenlenmemekle birlikte bu hakkın unsurları olan bilgilendirilme hakkı, açıklamada bulunabilme hakkı ve açıklamaların dikkate alınması yükümlüğüne ilişkin düzenlemeler farklı kavramlar altında Sözleşmenin 6. maddesinde güvence altına alınmaktadır. ${ }^{12}$

Hukuki dinlenilme hakkının temel unsuru bilgilendirilme hakkıdır. Muhakemeye katılanların muhakeme sürecinde sahip olduğu haklarını etkin bir şekilde kullanabilmesi haklarındaki isnadın ve verilen kararların bildirilmesine bağlıdır. Bilgilendirme çeşitli şekillerde olabilmekle birlikte inceleme konumuz bakımından verilen kararların hazır bulunan ilgilisine açılanması, hazır bulunmayan ilgilisine ise usulüne göre bildirilmesi ile gerçekleşir.

Kararların ilgilisine bildirilmesinin amacı, kişiyi, verilen kararın sonuçları ve gerekçeleri hakkında bilgilendirilmesi suretiyle özellikle karara karşı kanun yoluna başvurulması gerekip gerekmediği sorununu tartmasını ve değerlendirmesini sağlayabilecek bir duruma getirmektir. ${ }^{13}$

Diğer taraftan ceza muhakemesinde kararların ilgilisine bildirilmesine ilişkin düzenlemeler muhakeme sürecinin usulüne uygun şekilde gerçekleștiğini, özellikle de kişiye hukuki dinlenilme hakkının sağlandığını ispata hizmet ettiği için, ilgili kişinin kararın bildirilmesinden feragati geçerli değildir. $^{14}$

\section{HAKIM VE MAHKEME KARARLARININ ILGILISINE BILDIRILMESI}

Ceza muhakemesinde hakim ve mahkeme kararlarının önemine binaen bu kararların ilgilisine bildirilmesi CMK md. 35’te özel olarak düzenlenmiştir. Bu hükme göre, ilgili tarafın yüzüne karşı verilen karar kendisine açıklanır ve isterse kararın bir örneği de verilir. Koruma tedbirlerine

9 Hukuki dinlenilme hakkına ilişkin Alman hukukundaki düzenlemeler hakkında bkz. Abdullah Batuhan Baytaz, Ceza Muhakemesi Hukukunda Sanığın Hukuki Dinlenilme Hakkı, (On İki Levha 2021) 53 vd.

10 Baytaz (n 9) $10 \mathrm{vd.}$

11 ibid 12, 34.

12 Baytaz (n 9) 82.

13 Wesslau (n 8), StPO $\$ 35$ Kn. 1; Maul (n 8) StPO $₫ 35$ Kn. 1; Brian Valerius StPO $\$ 35$ Kn. 1, in: Hans Kudlich (Ed), Münchener Kommentar zur Strafprozessordnung, StPO, Cilt 1: \$\$ 1-150, (1. Bas1, 2014); ayrica bkz. ibid 169.

14 Wesslau (n 8) StPO $\$ 35$ Kn. 2. 
ilişkin olanlar hariç, aleyhine kanun yoluna başvurulabilecek hakim veya mahkeme kararları, hazır bulunamayan ilgilisine tebliğ edilir. İlgili taraf serbest olmayan bir kişi veya tutuklu ise tebliğ edilen karar, kendisine okunup anlatılır. Bu hükme göre, mahkeme ve hakim kararlarının ilgilisine bildirilmesi esas itibariyle üç şekilde söz konusu olmaktadır: İlgili tarafın yüzene karşı verilen kararlar kendisine açıklanarak bildirilecektir. Eğer kararın verildiği sırada ilgili taraf hazır değilse karar kendisine tebliğ edilerek bildirilecektir. Kararın verildiği sırada hazır olmayan ilgili kişi serbest olmayan bir kişi veya tutuklu ise karar, hem tebliği edilerek hem de okunup anlatılarak bildirilecektir.

Söz konusu bu üç usul incelenmeden önce bildirilmesi gereken hakim veya mahkeme kararları ile ilgili kişi veya taraftan ne anlaşılması gerektiği üzerinde durulması gerekmektedir

\section{A. BILDIRILMESI GEREKEN HAKIM VE MAHKEME KARARLARI}

Md. 35'in madde başlığı genel bir ifade olarak "kararların açıklanması ve tebliği” adını taşımakla birlikte, maddenin düzenleniş yeri, md. 33 ve 34 'ün konusu ve md. 35/2'nin ifade şekli dikkate alındığında savcılık kararlarının bildirilmesinin madde kapsamında düzenlenmediği anlaşılmaktadır. ${ }^{15}$ Çünkü birbirleri ile bağlantılı olan md. 33 hakim ve mahkeme kararlarının verilme usulünü, md. 34 bu kararların gerekçeli olmasını ve md. 35 ise söz konusu kararların bildirilmesini düzenlemektedir. CMK md. 35 'in kaynağını oluşturan Alman CMK $\$ 35$ ’te de sadece "kararlardan" (Entscheidungen) bahsedilmekle birlikte, doktrinde Alman CMK $\$ 33-\$ 35$ a hükümlerinin savcılık kararlarını kapsamadığı kabul edilmektedir. ${ }^{16}$ Nitekim $₫ 33-\S 35$ a hükümleri, Kanunda, mahkeme kararları alt başlı̆̆ı altında düzenlenmiştir.

Md. 35 fik. 1 ve fik. 3'te sadece "karar"dan, md. 35/2'de ise "hakim veya mahkeme kararları"ndan bahsedilmektedir. Kanun koyucunun niçin farklı ifadeler kullandığı madde gerekçesinde açıklanmamıştır. Kanaatimizce maddenin 2. fikrasında olduğu gibi 1. ve 3. fikralarında da kastedilenin yine hakim veya mahkeme kararlarıdır. Yukarıda belirtildiği üzere savcılık kararları madde kapsamında düzenlenmemiştir.

Bilindiği üzere ceza muhakemesinde yargılama yapan makamlar hakimlik ve mahkeme olmak üzere bir ayrıma tabi tutulmakta, buna uygun olarak verdikleri kararlar da hakimlik kararları ve mahkeme kararları olarak iki ayrı kategoride değerlendirilmektedir. Mahkeme kural olarak kovuşturma evresinde, özellikle de duruşma ve son karar aşamalarında yargılama görevi yapan makam iken, hakimlik ise mahkemenin görevi dışında kalan yargılama faaliyetlerini yapmakla görevlendirilen

15 Doktrinde Baytaz (n 9) 195, 35. maddenin 1. fikrasının savcılık kararları bakımından da uygulanmasının önünde bir engel söz konusu olmadığını ancak Cumhuriyet savcısının şüphelinin yüzüne karşı aldığı bir kararın bulunmaması sebebiyle bu düzenlemenin uygulanması imkânı olmadığını belirtmektedir. Diğer taraftan seri muhakeme usulü kapsamında yer alan suçlar hakkında Cumhuriyet savcısı tarafından yaptırım belirlenmesi kararı verilmesine ilişkin CMK md. 250 ve Ceza Muhakemesinde Seri Muhakeme Yönetmeliğinde detaylı düzenlemeler yapılmıştır. Bu konuda ayrıntılı bilgi ve eleştiriler için bkz. Muhammed Emre Tulay, 'Seri Muhakeme Usulü (CMK m. 250)', (2020) (2), İzmir Barosu Dergisi 117, 132 vd.

16 Maul (n 8) StPO $\$ 35$ Kn. 2; Hanns Larcher, StPO $\$ 35$ Kn. 1, in: Jürgen Graf (ed), BeckOK StPO mit RiStBV und MiStra (39. Edition, Stand: 01.01.2021). 
makamdır. Hakimliğin, naip hakim, istinabe olunan hakim, sulh ceza hakimi, asliye ceza hakimi, ağır ceza mahkemesi başkanı gibi çeşitleri vardır. Bunların verdikleri kararlar "hakimlik kararı” olarak ifade edilmektedir. ${ }^{17} \mathrm{Md}$. 35'te yer alan "hakim kararı" ile kastedilen "hakimlik kararı"dır. Bu açıdan soruşturma evresinde sulh ceza hakimi tarafından verilen kararların bildirilmesi madde kapsamında olduğu gibi, istinabe olunan hakimin verdiği kararlar yanında naib hakim veya mahkeme başkanı tarafından verilen kararlar da hakimlik kararı olup, madde 35 kapsamında ilgilisine bildirilmesi gerekir.

\section{B. KARARLARIN BILDIRILECEĞi iLgILI Kişi}

Kararların, açıklanması veya tebliği suretiyle bildirileceği ilgili kişi kapsamına söz konusu karardan hakları veya hukuki statüleri etkilenecek her muhakeme katılanı dahildir. Ancak ilgili kişinin karardan dolayı zarar görmesi veya görecek olması gerekmez. ${ }^{18}$ Şahsi dava kaldırıldığı ve şikayete bağlı suçlarda şikayet şartının gerçekleşmesi halinde savcının soruşturma yapmak, kamu davası açmak ve davaya katılmak görevi olduğu için bütün soruşturma ve kovuşturmalarda savcılık ilgili kapsamındadır. ${ }^{19}$

Kararların bildirileceği ilgili kişi için md. 35’te “ilgili taraf”tan söz edilmektedir (fik. 1 ve 3). Madde metnindeki bu ifadeyi muhakemeye katılan ve verilen karardan hakları etkilenen ilgili kişiler ve savcılık olarak anlamak gerekir. Bu nedenle ilgili tarafı sadece kanun yoluna başvuru hakkı bulunanlarla sinırlı olarak anlamamak gerekir. ${ }^{20}$

Diğer taraftan ceza muhakemesi gerçek anlamda bir taraf muhakemesi olmadığı için Cumhuriyet savcısını da taraf olarak nitelendirmek yerinde değildir. Muhakemenin tarafı olmadığı halde verilen kararların Cumhuriyet savcılığına da bildirilmesi gerektiği konusunda bir tereddüt yoktur. Yine muhakemede tanık veya bilirkişi olarak görev yapanlar da muhakemenin tarafı olmadıkları halde haklarındaki kararların (örneğin, gelmemesinin neden olduğu zararların tazminine ilişkin kararların) kendilerine bildirilmesi gerekir. Bu nedenlerle madde metninde "taraf" ifadesinin kullanılması isabetli olmamıştır. Nitekim kaynak Alman CMK \$35/1’te kararların “ilgili kişiye” bildirilmesinden söz edilmektedir. ${ }^{21}$

17 Hakimlik ve mahkeme kararları ayrımı ve bu ayrıma bağlanan sonuçlar hakkında bkz. Yenisey ve Nuhoğlu (n 2) 238; Fahrettin Demirağ, Örneklerle Ceza Muhakemesi Hukuku İslemleri ve Adli Yazışmalar, (2. Bası, Seçkin 2020) 52 vd.; Şahin ve Göktürk (n 1) 232; Mustafa Özen, Ceza Muhakemesi Hukuku Dersleri, (3. Bası, Adalet 2018) 187 vd.

Valerius (n 13) StPO $\$ 35$ Kn. 4; Wesslau (n 8) StPO $\$ 35$ Kn. 4.

19 Alman hukukunda re’sen soruşturulup kovuşturulan suçlar açısından savcılığın daima ilgili kişi kapsamında olduğu, ancak şahsi davalarda savcının kovuşturmayı üstlenmediği sürece ilgili kişi kapsamına girmediği belirtilmektedir: Bkz. Larcher (n 16) StPO $\$ 35$ Kn. 2; ayrica bkz. Wesslau (n 8) StPO $\$ 35$ Kn. 4.

20 İlgili taraftan kastın CMK md. 260’ta sayılan kanun yollarına başvurmaya hakkı bulunan kişiler olduğu görüşü için bkz. Ali Parlar, CMK Şerhi (3. Bası, Bilge 2017) 9'dan aktaran Yenisey ve Nuhoğlu (n 2) 130.

21 "İlgilinin huzurunda verilen kararlar, o kişiye açıklanmak suretiyle o kişiye bildirilir." Madde metninin Türkçe çevirisi için Alman CMK’nın Türkçe çevirisi için bkz. Feridun Yenisey ve Salih Oktar, Alman Ceza Muhakemesi Kanunu/ Strafprozessordnung (StPO) (2. Bası, Beta 2015) 20. 
Kararların bildirileceği ilgili kişi öncelikle şüpheli veya sanıktır. Bu nedenle müdafi yanında şüpheli veya sanığa da kararların bildirilmesi gerekir. Aşağıda açıklanacağı üzere, Yargıtay’nn TK md. 11 hükmüne dayanarak, vekilin ceza muhakemesindeki karşllı̆̆ının müdafi olduğu ve müdafie yapılan tefhim veya tebligattan sonra ayrıca sanığa da tebligat yapılmasının gerekli olmadığı yönündeki görüşü isabetli değildir.

Mağdur ve suçtan zarar görenler de madde kapsamında ilgili kavramına dahildir. Bu nedenle verilen kararlardan etkilenen mağdur, şikayetçi veya suçtan zarar gören ve katılana da kararın bildirilmesi gerekir. ${ }^{22}$ Yargıtay istikrarlı ve isabetli bir şekilde duruşmadan haberdar olmayan mağdura, şikayetçiye veya suçtan zarar görene gerekçeli karar tebliğ edilmemiş ise temyiz aşamasında bu eksiklik giderilmeden temyiz incelemesi yapılamayacağına karar vermektedir. ${ }^{23}$

\section{ILGILININ YÜZÜNE KARŞI VERILEN KARARLARIN AÇIKLANMASI VE BIR ÖRNEĞININ VERILMESI}

\section{KARARIN ILGILISINE AÇIKLANMASI}

Madde metninde yer alan "kararın açıklanmasından" maksat, verilen kararın hazır olan ilgilisine sözlü olarak bildirilmesi, yani duyurulmasıdır. ${ }^{24}$ Kararın hazır olan ilgilisine açıklanması, heyet halinde çalışan mahkemelerde mahkeme başkanı, diğer mahkemelerde ve hakimliklerde ise hakim tarafından yapılmalıdır. Kararın ilgilisine açıklandığının duruşma tutanağına geçirilmesi (md. 221/1-h), duruşma dışında verilen kararlarda ise bu hususun yazılı olarak tespit edilmesi gerekir. ${ }^{25}$

22 Gökcen, Balcı, Alşahin ve Çakır (n 1) 268.

23 Yargitay CGK, E 2016/15-228 K 2020/46, 20.01.2020; “Temyiz mahkemesince bir temyiz davasının görülebilmesi için, temyiz kanun yoluna bașvuru hakkı bulunanların tamamının kararı tefhim veya tebliğ yoluyla öğrenmelerinin sağlanması kanuni bir zorunluluktur. Nitekim 5271 Sayılı CMK'nın "Kararların açıklanmast ve tebliği" başlıklı 35. maddesinin ikinci fikrasında; "Koruma tedbirlerine ilişkin olanlar hariç, aleyhine kanun yoluna başvurulabilecek hâkim veya mahkeme kararları, hazır bulunamayan ilgilisine tebliğ olunur" hükmü yer almaktadir.// Yerel Mahkemece katılana gerekçeli karar tebliğ olunmamıs ise temyiz aşamasında bu eksikliğin Özel Dairece 2797 Sayll Yargıtay Kanunu’nun 40. maddesi uyarınca verilecek, uygulamada "tevdi kararı" adı verilen kararla mahallinde mahkemesince giderilmesinin istenilmesi gerekir; yoksa temyiz incelemesine geçilerek bozma kararı verilmek suretiyle bu eksiklik giderilemez. Aksi hâlde temyiz kanun yoluna başvuru hakkı bulunan bir tarafın kararı öğrenmesi sağlanmadan temyiz incelemesi yapılmış olur ve aleyhe temyiz bulunmayan hâllerde bozulan hükümdeki ceza miktarı sanık lehine kazanılmış hak teşkil eder.// Kişilerin hak arama hürriyetlerinin Anayasa ve diğer kanunlarla güvence altına alındığı ve bu hakkın kullanılabilmesi için devlet işlemlerinin kişilere usulüne uygun olarak bildirilmesi gerektiği, bu bağlamda itiraza konu hükümlerin kurulduğu 01.10.2014 tarihli oturuma katılmayan katılan ...'in yokluğunda verilen kararın adı geçen katılana tebliğ edilmediği anlaşıldığından, 5271 Sayılı CMK'nın 35 ve 260. maddelerine göre hükümlerin Beşiktaş 15. Noterliğinin 15.12.2008 tarihli ve 13192 yevmiye numaralı vekaletnamesi ile katılan ...'in vekilliğini üstelenen ve soruşturma evresinde görev yapan Av....in vekilliğinin devam edip etmediğinin araştırılarak vekilliğinin devam ettiğinin belirlenmesi hâlinde Av....a, devam etmediğinin belirlenmesi hâlinde ise katılan ...e usulünce tebliğ edilmesi gerekmektedir." Aynı yönde bkz. CGK, E 2016/23-1344 K 2020/218, 21.05.2020; CGK, E 2017/1-177 K 2019/486, 20.06.2019; CGK, E 2017/6-619 K 2018/674, 25.12.2018.

24 Nitekim aynı hükmün karşıllğı olan CMUK md. 33/1'de, "Alakadar tarafın yüzüne karşı ittihaz edilen kararlar kendisine tefhim olunur ve isterse kararın bir sureti de verilir." denilerek, kararların sözlü olarak bildirilmesinden bahsedilmektedir.

25 Wesslau (n 8) StPO $\$ 35$ Kn. 7; Lutz Meyer-Gossner, Strafprozessordnung StPO, Gerichtsverfassungsgesetz, Nebengesetze und ergänzende Bestimmungen, (56. Bas1, 2013), StPO $₫ 35$ Kn. 5; Valerius (n 13) StPO $₫ 35$, Kn. 11, 13. 
Duruşma sırasında verilmiş olsa bile ara kararlarda yazılı metnin aynen okunması gerekmeyip karar içeriğine ilişkin önemli hususların ve kararın gerekçesinin okunması veya sözlü şekilde açılanması yeterlidir. $^{26}$

Kararın açıklanacağı şüpheli veya sanık, meramını anlatabilecek derecede Türkçe bilmiyorsa açıklama, atanacak tercüman vasıtasıyla yapılmalıdır. ${ }^{27} \mathrm{Md}$. 202/1'de sadece, "duruşmadaki iddia ve savunmaya ilişkin esaslı noktalar tercüme edilir” deniliyorsa da adil yargılanma hakkının gereği olarak bu hüküm mümkün olduğunca geniş yorumlanmalı ${ }^{28}$ ve karalarda, kararın esaslı noktaları, hükümlerde ise hüküm fıkrası ile gerekçesinin tercüme edilmesi gerekir. ${ }^{29}$ Avrupa İnsan Hakları Mahkemesi (AİHM) içtihatlarına göre, sanığın adil yargılanma hakkından yararlanmasını güvence altına alacak ölçüde, kararlar da dahil olmak üzere, anlaması gereken bütün soruşturma ve kovuşturma işlemlerinin mahkeme dilini bilmeyen şüpheli veya sanığa tercüme edilmesi gerekir. ${ }^{30}$

Önemi nedeniyle kanun yolu başvuru hakkının bildirilmesi md. 231/1-4’te özel olarak düzenlemiştir. Buna göre, duruşma sonunda verilen hükmün hüküm fikrası hazır bulunan sanığa okunarak ana çizgileri ile anlatılmalı ve ayrıca başvurabileceği kanun yolları, mercii ve süresi de açıklanmalıdır (fık. 1-2). Yine md. 232/6 uyarınca hüküm fikrasında, kanun yollarına başvurma "olanağının bulunup bulunmadığının, başvuru olanağı varsa süresi ve merciinin tereddüde yer vermeyecek şekilde açıcça gösterilmesi gerekir." Her ne kadar md. 231/2 ve 232/6'da, kanun yolu başvuru şeklinin de bildirileceğine ilişkin bir düzenlemeye yer verilmemişse de, bütün hakim ve mahkeme kararlarının bildirilmesinde geçerli genel hüküm niteliğinde olan md. 34/2 uyarınca kanun yoluna nasıl başvurulacağının da hazır bulunan sanığa bildirilmesi gerekir. Diğer taraftan md. 34/2 uyarınca kanun yolu başvuru hakkındaki bilgilendirme sadece sanığa değil, ilgili karar hakkında kanun yoluna başvuru hakkı olan diğer kişilere (duruma göre mağdur, katılan, tanık gibi) de yapılması zorunludur.

Kanun yolu başvuru hakkının bildirilmesine ilişkin md. 34/2 hükmünde "başvurulabilecek kanun yolu, süresi, mercii ve şekilleri belirtilir” deniliyorsa da bu hükmün kaynak Alman CMK’da (\$ 35a) ${ }^{31}$ olduğu gibi, kanun yolu başvuru hakkının öğretilmesi veya kanun yolu başvuru imkanları hakkında bilgilendirme şeklinde anlaşılması daha doğru olacaktır. Çünkü burada hak arama özgürlüğünün gerçekleştirilmesi için söz konusu olduğu için ilgili kişiye hangi kanun yoluna ve nasıl başvurabileceği konusunda anlayacağı şekilde bilgilendirme yapılmalıdır.

26 Wesslau (n 8) \$ 35 Kn. 6; Meyer-Gossner (n 25) StPO $\$ 35$ Kn. 5; Valerius (n 13) StPO $\$ 35$, Kn. 10.

27 Şüpheli veya sanı̆̆ın hukuki dinlenilme hakkı açısından tercümandan yararlanma hakkı konusunda detaylı inceleme için bkz. Baytaz (n 9) $304 \mathrm{vd}$.

28 ibid 319.

29 Hukuki dinlenilme hakkı açısından hangi hususların tercüme edilmesi gerektiği konusunda bkz. ibid 320 ve Alman Hukuku için bkz. Wesslau (n 8) StPO $\$ 35$ Kn. 23.

30 Valerius (n 13) StPO $\$ 35$ Kn. 7; Mehmet Öncü, 'AİHS’nin $6 \$ 3$ e) Hükmü Anlamında Tercüman Yardımından Yararlanma Hakkı' (2014) 16 (Prof. Dr. Hakan Pekcanıtez’e Armağan Özel Sayı) Dokuz Eylül Üniversitesi Hukuk Fakültesi Dergisi, 4457, 4473; Baytaz (n 9) 318-319. Bu konuda ayrıca bkz. Wesslau (n 8) StPO \$ 35 Kn. 23; Ali Şahin Kılıç, 'Tercümandan Faydalanma Hakkı Çerçevesinde Sanığın Seçtiği Dilde Savunma Yapması Üzerine Bir Değerlendirme’ (2016) 65(4), Ankara Üniversitesi Hukuk Fakültesi Dergisi, 2101, 2111.

$31 \$ 35$ a’nın madde başlığı "kanun yolu başvurusunun öğretilmesi” adını taşımaktadır. 
Kanun yolu başvuru hakkı konusunda bilgilendirme hem ilgili kişinin yüzüne karşı verilen kararların açıklanmasında hem de ilgilinin yokluğunda verilen kararların bildirilmesinde yapılması gerekir. Aslında md. 34/2 hükmünün kanun yolu başvuru hakkı konusunda bilgilendirme adı altında ayrı bir madde olarak düzenlenmesi gerekirdi. Çünkü md. 34 başlığı kararların gerekçeli olmasına ilişkin olup bu husus maddenin 1. fikrasında düzenlenmiştir. Maddenin 2. fikrası ise kanun yolu başvurusuna ilişkin olup kararların gerekçesi ile ilgili değildir. Nitekim kaynak Alman CMK’da $₫$ $35 a^{3} \mathrm{da}^{32} \mathrm{ek}$ bir düzenleme yapılarak, kanun yolu başvurusunun öğretilmesi adı altında konu detaylı bir şekilde düzenlenmiştir.

Kanun yolu başvuru hakkı konusundaki bilgilendirmenin yapılmaması, eksik veya hatalı yapılması hükmün bozulması nedeni oluşturur. Uygulamada kanun yolu başvuru hakkının bildirilmesinde gerekli özenin gösterilmediği Yargıtayın md. 34 ile ilgili olarak verdiği çok sayıda bozma kararlarından anlaşılmaktadır. Ayrı bir çalışma konusu olacak kadar kapsamlı olan bu konuya burada kısaca işaret etmekle yetinilecektir. ${ }^{33}$

Kanun yolu başvuru hakkı konusundaki bilgilendirme açık, yanlış anlamaya neden olmayacak şekilde ve tam olmalıdır. Bilgilendirmede hangi kanun yolu başvuru imkanının (itiraz, istinaf veya temyiz) bulunduğu, kanun yolu başvurusunun hangi hakim veya mahkemeye, hangi süre içinde, hangi şekilde (bir dilekçe ile veya tutanağa geçirilmek koşulu ile zabıt kâtibine beyanda bulunmak suretiyle) yapılması gerektiği şüpheye yer vermeyecek şekilde açıkça belirtmelidir. ${ }^{34}$ Ayrıca başvuru için genel hükümlerden ayrilan özel bir düzenleme söz konusu ise (örneğin, CMK md. 263) bu konuda da bilgilendirme yapılmalıdır. ${ }^{35}$ Hükmün tefhimi sırasında hazır buluna sanık kanun yolu başvuru hakkı konusunda usulüne uygun şekilde bilgilendirilmişse, daha sonra tebliğ edilen kararda yeninden bilgilendirme yapılması zorunlu değildir. ${ }^{36}$

Diğer taraftan Alman hukukunda, mahkeme kararına karşı temyiz yoluna başvuru imkanı varsa, temyiz dilekçesinin gerekçeli olması konusunda da bilgilendirme yapılması gerektiği kabul edilmektedir. ${ }^{37} \mathrm{Bu}$ nedenle kanun yoluna ilişkin bilgilendirme kapsamında, temyize ilişkin on beş günlük başvuru süresi yanında, CMK md. 295/1 uyarınca bölge adliye mahkemesinin gerekçeli kararının tebliğinden itibaren işlemeye başlayan yedi günlük süre içerisinde gerekçeli temyiz dilekçesinin verilmesi gerektiği konusunda da bilgilendirme yapılması gerekir. Bu husus Yargıtay kararlarında yerinde ve isabetli içtihatlarında vurgulanmaktadır. Örneğin, 14. Ceza Dairesinin (CD) 12.03.2020 tarihli kararında ${ }^{38}$ bu husus, "CMK'nin 34/2. madde ve fikrasinda bulunan Kararlarda,

$32 \S 35$ ảnın konu ile ilgili birinci cümlesi şu şekildedir: "Belli bir süre içinde kullanılabilen bir kanun yolu başvurusu ile karşı konulabilen bir kararın bildirilmesinde, ilgiliye kanun yolu başvuru imkanları ve bunun için öngörülen süreler ile başvurun şekilleri öğretilir." Madde metninin Türkçe çevirisi için ayrıca bkz. Yenisey ve Oktar (n 21) 21.

Bkz. CGK, E 2016/13-1281 K 2019/21614.03.2019; Alman hukuku için bkz. Wesslau (n 8) StPO § 35a Kn. 8; Maul (n 8) StPO $\$ 35$ a Kn. 9.

35 Wesslau (n 8) StPO $\$ 35 a$ Kn. 9.

36 Maul (n 8) StPO $\$ 35$ a Kn. 10.

37 Wesslau (n 8) StPO \$ 35a Kn. 8; Valerius (n 13) StPO \$35a Kn. 18.

38 Yargitay 14. CD, E 2019/4139, K 2020/1978, 12.03.2020. 
başvurulabilecek kanun yolu, süresi, mercii ve şekilleri belirtilir şeklindeki düzenlemeler nazara alındığında, Bölge Adliye Mahkemesince verilen kararda aynı Kanunun 291/1. maddesindeki temyize ilişkin on beş günlük kanuni sürenin belirtilmesinin yan sıra süresinde verilen temyiz dilekçesiyle talep edildiği takdirde gerekçeli hükmün tebliğinden işlemeye başlayan yedi günlük süresi içerisinde gerekçeli temyiz dilekçesi verilmesinin zorunlu olduğuna dair CMK’nın 295/1. maddesinin de yer alması gerektiğinin gözetilmemesi nedeniyle sanık müdafisinin kanuni süresinden sonra gerekçeli temyiz dilekçesi sunduğundan bahisle vaki temyiz isteminin reddi gerektiği yönündeki tebliğnamedeki görüşe iştirak edilmemiştir." denilerek açıklanmıştır. ${ }^{39},{ }^{40}$ Yine Yargıtay Ceza Genel Kurulunun (CGK) 17.03.2021 tarihli kararında isabetli olarak, temyiz nedenlerini içeren ek dilekçenin gerekçeli kararın tebliğinden itibaren yedi gün içeresinde verilmesi gerektiğinin bildirilmesinin zorunlu olduğuna karar vermiştir. ${ }^{41}$ Ancak CGK’nın diğer bazı kararlarında ise tam aksi yönde içtihatta bulunulmuştur. Örneğin, CGK’nın 17.11.2020 tarih ve E 2019/459 K 2020/459 sayılı kararındaki; “... ek dilekçe için öngörülen (7) günlük sürenin, mahkeme kararlarının sonuç bölümünde gösterilmesi zorunlu olan, hükme karşı başvurulabilecek kanun yolu süresi olmadiğı, dolayısıyla temyiz nedenlerini bildirir ek dilekçe için öngörülen bu sürenin ilgilisine bildirilmeyişinin mahkemeye erişim hakkına orantısız bir müdahale olarak görülemeyeceği ve ilgilisine bildirilmesi hususunda zorunluluk bulunmadığ kabul edilmelidir.” görüşünü savunmuştur. ${ }^{42}$

Yargıtay kararlarından anlaşıldığı üzere uygulamada bu konuda ciddi sıkıntılar olduğu, bölge adliye mahkemelerince verilen bazı kararlarda gerekçeli kararın tebliğinden itibaren yedi günlük süre içinde temyiz nedenlerini içeren ek dilekçenin verilmesi gerektiğine (md. 295/1) ilişkin bilgilendirmenin yapılmadığı anlaşılmaktadır. Kanaatimizce, kanunda öngörülen bu zorunluluğun yerine getirilmemesinin olumsuz sonuçları muhakemeye katılanlara yüklenmemelidir. Yukarıda açıklandığı üzere hukuki dinlenilme hakkının güvencesini oluşturan md. 34/2 hükmü, kanun yolu başvuru hakkı konusunda kapsamlı bir bilgilendirme yükümlülüğü içermektedir. Kanunda öngörülen yedi günlük süre içinde temyiz nedenlerini içeren dilekçenin verilmesi zorunluluğu da hem kanun yolu başvuru süresi ile ilgili hem de başvuru şekline ilişkindir. Bu nedenle Yargıtayın aksi yöndeki görüşlerinin isabetli olmadığını düşünüyoruz.

39 14. Ceza Dairesinin süreklilik arz eden aynı yöndeki diğer kararları için bkz. E 2020/4400 K 2020/3209, 08.07.2020; E 2020/749 K 2021/372, 21.01.2021.

40 16. Ceza Dairesinin içtihatları da aynı yöndedir. Örneğin, Dairenin 04.02.2020 tarihli (E 2019/9766, K 2021/580) kararında, "Bölge Adliye Mahkemesi tarafından 21.03.2018 tarihinde tefhimle verilen karara karşı, sanık müdafi tarafından 22.03.2018 tarihinde temyiz sebeplerini içermeyen süre tutum dilekçesi verildiği, Bölge Adliye Mahkemesinin gerekçeli kararının sanık müdafiine 10.05.2018 tarihinde tebliğ edildiği, sanık müdafiince 11.06.2018 tarihinde ayrıntılı temyiz dilekçesinin, CMK’nın 295. maddesinde belirtilen 7 günlük süreden sonra sunulduğu görülmüş ise de, Bölge Adliye Mahkemesi gerekçeli kararının hüküm fıkrasında ve sanık müdafiine gerekçeli kararı tebliğ eden tebligat zarfında CMK’nın 295. maddesinde düzenlenen 7 günlük süreye ilişkin bir ihtaratın bulunmadığı anlaşıldığından tebliğnamedeki temyiz talebinin reddine karar verilmesi yönündeki düşünceye iştirak edilmemiştir." Denilerek bu husus vurgulanmaktadır. 16 CD’nin aynı yöndeki kararları için bkz.: E 2019/1213, K 2020/1885, 25.02.2020; E 2019/7453, K 2021/901, 10.02.2021; E 2019/ 7188, K 2020/6137, 09.12.2020; E 2019/ 10264, K 2021/ 48, 25.05.2021.

41 CGK, E 2019/554, K 2021/117, 17.03.2021.

42 Aynı yöndeki CGK’nın diğer kararları için bkz.: E 2019/ 549, K 2020/402, 06.10.2020; E 2019/171, K 2020/169, 10.03.2020; E 2019/ 354, K 2020/ 394, 01.10.2020. 
Kanun yolu başvuru hakkının bildirilmesindeki hukuka aykırılıklar kanun yolu başvuru süresinin işlemesine engel olmamakla birlikte ilgili kişi, CMK md. 40/2 uyarınca süreyi geçirmekte kusursuz kabul edilmekte ve eski hale getirme talebinde bulunabilmektedir. ${ }^{43}$

Karar, ilgilinin huzurunda verilmişse, kanun yolu bilgilendirmesi sözlü, yokluğunda verilmişse yazılı ve kural olarak da tebligat yoluyla yapılmalıdır. ${ }^{44} \mathrm{Md}$. 34/2'ye göre bilgilendirme, ilgili karara yazılması gerekli olup, ayrı bir yazı ile bildirilmesi gerekli değildir. Md. 236/6 uyarınca da hükümlerde, kanun yoluna başvurma imkanı varsa bunun süresi ve merciinin hüküm fikrasında tereddüde yer vermeyecek şekilde açıkça gösterilmesi gerekir.

TK md. 11'e göre, vekil ile takip edilen işlerde tebligat vekile yapılmalıdır. Yargıtaya göre, vekilin ceza muhakemesindeki karşıllı̆̆ olan müdafie yapılan tefhim veya tebligattan sonra ayrıca sanığa da tebligat yapılması gerekli olmayıp, gerekmediği halde yapılan tebligat temyiz süresini yeniden başlatmaz; bu nedenle hükmün sanık müdafiinin yüzüne karşı tefhiminden itibaren temyiz süresi işlemeye başlar ve gerekmediği halde sanığa yapılan tebligat yeni bir süre başlatmadığı gibi yeni bir temyiz hakkı da doğurmaz. ${ }^{45}$

Kanun yolu başvuru süresinin başlaması açısından Yargtay'in görüşü yerinde olmakla birlikte, sanığın yokluğunda ve müdafin yüzüne karşı verilen kararın ayrıca sanığa tebliğ edilmeyeceğine ilişkin içtihadı yerinde değildir. Çünkü TK md. 11’e göre, “Ceza Muhakemeleri Usulü Kanununun, kararların sanıklara tebliğ edilmelerine ilişkin hükümleri saklıdır." Yukarıda açıklandığı üzere, CMK md. 35/2 hükmüne göre, aleyhine kanun yoluna başvurulabilecek hakim veya mahkeme kararları, hazır bulunamayan ilgilisine tebliğ edilecektir. Hazır bulunamayan ilgilisi kavramının kapsamına bir müdafi tarafından temsil edilsin veya edilmesin her şeyden önce şüpheli veya sanık girer. Yukarıda açıklandığı üzere ceza muhakemesinde sadece aleyhine kanun yoluna başvurulabilecek kararların değil, adil yargılanma hakkının gereği olarak her türlü mahkeme ve hakim kararlarının verildiği sırada hazır olmayan ilgilisine bildirilmesi gerekir. ${ }^{46} \mathrm{CMK}$ md. 35 hükmünden şüpheli veya sanığın müdafi tarafından temsil edilmesi halinde tefhim veya tebliğin sadece müdafie yapılacağı, şüpheli veya sanığa yapılacak bildirimin geçersiz olacağ şseklinde bir sonuca ulaşılamaz. Nitekim 7201 sayılı TK’nın 11. maddesini değiştiren 6.6.1985 tarih ve 3220 sayılı Kanunun 5. maddesinin gerekçesinde bu husus açık bir şekilde ifade edilmektedir: "Diğer taraftan, Ceza Muhakemeleri Usulü Kanununun 'kararların tefhim ve tebliği' başlığını taşıyan 33. maddesinde, ilgililerin yüzüne karşı verilen kararların tefhim olunacağı ve diğer kararların tebliğ edileceği esası kabul edilmiştir. Görülüyor ki her hükmün ilgiliye bildirilmesi CMUK.'nın ana ilkelerinden birini oluşturmaktadır. Kanun koyucu

43 Bu konuda ayrıntılı bilgi ve Yargıtay kararlarının incelenmesine ilişkin bkz. Faruk Turhan, 'Ceza Muhakemesinde Sürelerin Kusur Olmaksızın Geçirilmesinde Eski Hale Getirme’ iç Feridun Yenisey, İzzet Özgenç, Ayşe Nuhoğlu, Adem Sözüer, Faruk Turhan (edr), Dr. Dr. h.c. Silvia Tellenbacha Armağan, (Seçkin 2018) 1240 vd.

44 Maul (n 8) StPO \$ 35a Kn. 10.

45 CGK, E 2013/13-300, K 2014/286, 27.05.2014; Ünver ve Hakeri (n 2) 147.

46 Öztürk’e (Ed) göre, s. 288, ceza davalarında kararların müdafi yanında sanıklara da tebliği zorunlu olmalıdır. Aynı yönde, Özen (n 17) 194. 
bu konuda çok hassas davranmış, ilgililerin kanuni haklarını kullanabilmeleri için sanıkların karar ve hükümlerden haberdar edilmelerini öngörmüştür.”47

Diğer taraftan hakim veya mahkeme kararlarının şüpheli veya sanığa bildirilmesi ile kanun yolu başvuru süresinin başlamasını birbirinden ayırmak gerekir. Öncelikle şüpheli veya sanığın haklarının korunması açısından başvuru süresinin müdafie yapılan tefhim veya tebligat ile başladığının kabulü yerindedir. Ancak kendisine tebligat yapılan şüpheli veya sanığın süresinde bizzat yapmış olduğu kanun yolu başvurusu geçerli olup, müdafiin başvurusunu beklemeye gerek bulunmamaktadır. ${ }^{48}$ Müdafi yanında şüpheli veya sanığa yapılacak tebligat, kararın içeriği hakkında bilgi sahibi olmayı ve müdafiin kusurlu davranışı ile kanun yolu başvuru süresini geçirmiş olması halinde eski hale getirme imkanının bulunup bulunmadığının incelenerek koşullarının bulunması halinde eski hale getirme talebinde bulunma imkanı verebilecektir. ${ }^{49}$

\section{KARARIN BİR ÖRNEĞİNİN ILLGÍLISİNE VERILLMESI}

İlgilinin huzurunda verilip açıklanan kararın bir örneği talep üzerine ilgilisine verilecektir (md. 35/1). İlgili kişinin sadece kararın örneğini talep hakkı olup, dosyanın tamamının verilmesini isteme hakkı bulunmamaktadır. ${ }^{50}$ Ancak CMK’nın diğer hükümlerinde şüpheli, sanık veya mağdura dosyadaki belgelerin örneğini isteme hakkı verilmiştir. ${ }^{51}$ İlgili kişinin karar örneği verilmesi talebiyle herhangi bir ceza muhakemesi amacı gütmesi, örneğin karara karşı kanun yoluna başvuracak olması, gerekmediği gibi, niçin istediğine ilişkin bir gerekçe göstermesi de gerekmez; bu talep hakkına kanunda herhangi bir sınırlama getirilmemiştir. ${ }^{52}$ Talep üzerine karar örneğinin ilgiliye gecikmeksizin verilmesi gerekir. Bu nedenle örneğin, delil toplanması veya ikamesine ilişkin bir talebin reddine ilişkin karar duruşmadaki bir oturum sırasında verilmiş ve tutanağa geçirilmişse, ilgili kişinin talebi

47 Madde gerekçesinin devaminda; "Hal böyleyken Hukuk Usulü Muhakemeleri Kanununun eski 124. maddesinin mukabili olan Tebligat Kanununun 11.maddesinde geçen "vekil" kavramı çoğu zaman müdafi kavramıla aynı mahiyette telakki edilmekte, bu nedenle ceza yargılamasında, tebligat bakımından birbirinden farklı uygulamalara ve hatalı sonuçlardoğmasına sebep olmaktadır. Bilindiği gibi hukuk yargılamasındaki "vekil” ile ceza yargılamasındaki müdafi kavramları birbirinden farklıdır. Vekil, müvekkilden ayrı ve bağımsız bir statüye sahip değildir, bağımlıdır. Temsil ettiği kişinin talimatıyla hareket eder ve onun yokluğunda onun yerine geçer. Müdafi ise yalnızca ceza davasında söz konusudur. YCGK'nın 25.12.1978 gün ve 427/507 sayılı kararında da belirtildiği üzere, duruşma vekil için değil, sanık için yapılmaktadır. Akıbeti de sanığın özgürlüğ̈̈ veya mali durumu ile kısacası şahsı ile ilgili bulunmaktadır. Bu itibarla ceza davalarında kararların sanıklara tebliğ edilmesine gerek görmemek, müdafiine yapılan tebliği geçerli saymak adalet ilkeleriyle bağdaştırılamayacak bir durumdur. Işste yukarıda belirtilen görüşlerin ışığı altında uygulamaya açıklık getirmek için 11.maddenin 1. fikrası yeniden düzenlenmiştir." denilerek TK md. 11'in hukuk muhakemesinde uygulama alanı bulacağı açıkça ifade edilmiştir. Madde gerekçesi ve bu konudaki Yargıtay CGK kararının değerlendirilmesi hakkında bkz. Serap Keskin, 'Ceza Muhakemesinde Müdafie Yapılan Tebligat Sanığa Yapılmış Sayılır Mı?’' İstanbul Hukuk Fakültesi Mecmuası (1997) LV(3), 355 vd.

48 Ancak baro tarafından görevlendirilen zorunlu müdafiin yüzüne karşı yapılmış olan tefhim, kendisine zorunlu müdafi atandığından haberdar edilmeyen sanık açısından hukuki sonuç ifade etmediği gibi, temyiz süresini de başlatmaz: Yargitay CGK, E 2010/6-124 K 2010/156, 22.6.2010.

49 Kanun yolu başvuru süresinin geçirilmesinin müdafinin kusurundan kaynaklanması halinde sanığın eski hale getirme talebinde bulunup bulunamayacağı konusunda bkz. Turhan, (n 37) 1239-1240

50 Valerius (n 13) StPO $\$ 35$ Kn. 17; Wesslau (n 8) StPO $\$ 35$ Kn. 10.

51 CMK md. 153, 234; Yazı İşleri Yönetmeliği md. 100 ve 137.

52 Maul (n 8) StPO $\$ 35$ Kn. 8; Valerius (n 13) StPO $\$ 35$ Kn. 17; Wesslau (n 8), StPO $\$ 35$ Kn. 10. 
halinde duruşmanın tamamlanması beklenmeksizin tutanağın bir sureti kendisine verilmelidir. ${ }^{53}$ Ancak ilgili kişinin karar verilir verilmez hemen talepte bulunması gerekmez; talepte bulunmak için bir süre öngörülmediği için kararın kesinleşmesinden sonra da bir örneğinin verilmesi istenebilir. ${ }^{54}$ Karar örneğini verme yetki ve görevi, kararın kesinleşmesinden önce kararı veren mahkeme başkanı ve hakime, kesinleşmesinden sonra ise dava dosyasını muhafaza etmekle görevli mercie (yani savc1lı̆ga) aittir. ${ }^{55}$

Alman hukukunda karar örneğinin ilgiliye verilmesinin devlet sırrı nedeniyle sınırlandırılabileceği kabul edilmektedir. Özellikle kararın verilmesi Alman Ceza Kanunu $\$ 93$ anlamında devlet sırrını tehlikeye düşürecekse, kararın söz konusu kısımlarının ilgilisine verilmeyebileceği, ancak kararın tamamının mahkeme yazı işlerinde ilgilisi tarafından incelenmesine imkan sağlanması gerektiği belirtilmektedir. Ancak devlet sırrı da söz konusu olsa genel bir yasaklama yapılamaz. Karardaki gizli tutulmayı gerektiren olguların ilgili kişi tarafından Almanyảnın esenliğine zarar verecek şekilde kullanılacağından endişe etmek için somut bir neden varsa ancak kararın ilgilisine verilmesinin yasaklanabilmesi kabul edilmektedir. Bu gibi durumlarda en azından belli koşullar altında kararın bir örneğinin müdafie verilmesi gerekmektedir. Ayrıca gizli tutulması gereken sırların sadece fiili olgulara ilişkin olabileceği, hukuki açıklamaların hiçbir şekilde korunmaya değer sır olarak gizli tutulamayacağ 1 belirtilmektedir. ${ }^{56}$ CMK'da ise ilgilinin huzurunda verilen mahkeme veya hakim kararlarının devlet sırrına, ticari sırra veya özel hayata ilişkin olması halinde bu kararın tamamen veya kısmen ilgilisine verilmesini yasaklayan genel bir hükme yer verilmemiştir. Ancak devlet sırrına ilişkin konularda tanıkların dinlenmesi (md. 47) ve devlet sırrı niteliğindeki belgelerin incelenmesinde (md. 125) ve duruşmada aleniliğin kaldırılması veya sınırlandırılmasına ilişkin hususlarda özel düzenlemeler (md. 182-187) bulunmakla birlikte, bu durumlarda verilecek kararların gizli tutulmasına veya ilgilisine verilmesinin sınırlandırılmasına ilişkin bir hükme yer verilmemiştir. Aşağıda ele alınacağı üzere hakim ve mahkeme kararlarının hazır bulunmayan ilgilisine tebliğinde koruma tedbirleri açısından istisna getirilmiştir (md. 35/2).

Duruşma sırasında davaya ilişkin evrakın ilgili kişilere elden verilmesi ile ilgili TK md. 36 hükmü de hakim veya mahkeme kararlarının ilgilisine doğrudan bildirilmesinin bir çeşididir. ${ }^{57} \mathrm{TK}$ md. 36 ya göre, "Celse esnasinda veya kalemde, soruşturmaya, davaya ya da takibe ait evrakın, taraflara, ilgili üçüncü kişilere, katılana veya vekillerine tutanağa geçirilmek suretiyle veya imza karşıllğında, tebliğ konusu belirtilerek tevdii, tebliğ hükmündedir. Bu durumda ayrıca tebliğ mazbatası düzenlenmesi gerekmez ve masraf da alınmaz." Söz konusu düzenleme uyarınca duruşma sırasında verilen bir kararın ilgilisine elden verilmesi halinde bu husus tutanağa geçirilecektir. Madde metninde bu usulün de tebliğ hükmünde olduğu belirtilmişse de tutanağa geçirme işleminin hakim veya mahkeme

53 Valerius (n 13) StPO $₫ 35$ Kn. 20; Maul (n 8) StPO $₫ 35$ Kn. 9; Meyer-Gosner, StPO $₫ 35$, Kn. 6; Wesslau (n 8) StPO $₫ 35$ Kn. 13.

54 Maul (n 8) StPO $₫ 35$ Kn. 10; Wesslau (n 8) StPO $\$ 35$ Kn. 11; Valerius (n 13) StPO $\$ 35$ Kn. 21.

55 StPO/Wesslau, StPO $\$ 35$ Kn. 12; Maul (n 8) StPO $\$ 35$ Kn. 11; Valerius (n 13) StPO $\$ 35$ Kn. 21.

56 Maul (n 8) StPO $₫ 35$ Kn. 12; Valerius (n 13) StPO $\$ 35$ Kn. 19; Wesslau (n 8) StPO $\$ 35$ Kn. 14; Meyer-Gossner (n 25) $\mathrm{StPO} \$ 35 \mathrm{Kn} .8$.

57 Şahin ve Göktürk (n 1) 131. 
başkanı tarafından yapılması halinde gerçek anlamda bir tebliğ değil, vasıtasız olarak bildirme söz konusudur.

\section{ILGILININ YÜZÜNE KARŞI VERILMEYEN HAKIM VE MAHKEME KARARLARININ TEBLIĞi}

Yukarıda açıklandığı üzere hak arama özgürlüğünün kullanılabilmesi için muhakeme işlemlerinin usulüne uygun bir şekilde ilgilisine bildirilmesi gerekir. ${ }^{58}$ Bildirim usullerinden biri de kararın tebliğidir. Bir hakim veya mahkeme kararı ilgilinin hazır olmadığı sırada verilmişse bunun nasıl bildirileceği md. 35/2'de gösterilmiştir. Bu hükme göre, koruma tedbirlerine ilişkin olanlar hariç, aleyhine kanun yoluna başvurulabilecek hakim veya mahkeme kararları hazır bulunamayan ilgilisine tebliğ edilecektir. Md. 35/2'de tebliğ zorunluluğu düzenlenmiş, tebligat yazısının hangi merci tarafından yazılacağı ve hangi usulde yapılacağı ise md. 36-37’de gösterilmiştir. Tebligatın yapılmasına ilişkin hususlar ise detaylı olarak TK'da düzenlenmiştir.

Kanuna göre bir hakim veya mahkeme kararının hazır bulunamayan ilgilisine tebliğ zorunluluğu için dört koşulun bulunması gerekmektedir. Bunlar; kararın hakim veya mahkeme tarafından verilmiş bir karar olması, karara karşı kanun yoluna başvurulabilecek olması, kararın koruma tedbirlerine ilişkin olmaması ve kararın verildiği sırada ilgilinin hazır bulunamamış olmasıdır.

\section{KARARIN, HAKIM VEYA MAHKEME KARARI OLMASI}

Yukarıda açıklandığı üzere md. 35/2 uyarınca bildirim zorunluluğu sadece hakim ve mahkeme kararları için kabul edilmiş olup, savcılık kararlarının tebliği madde kapsamında değildir. Ancak bu düzenleme, savcılık kararlarının ilgilisine tebliğ edilmeyeceği anlamına gelmez. Soruşturma evresinde savcının vermiş olduğu kararlara karşı kural olarak kanun yolu başvurusu kabul edilmemiştir. Ancak soruşturma yapılmasına yer olmadığı kararı, kamu davasının açılmasının ertelenmesi kararı, kovuşturmaya yer olmadığı kararı gibi bazı savcılık kararlarına karşı itiraz edilebilmesi kabul edilmiş olup (md. 158/6, 171/2, 172/1), bu kararların ilgilisine bildirilmesi savcılık tarafından yapılmalıdır. $\mathrm{Bu}$ hallerde bildirim, ilgili maddelerde belirtilen usule ve TK’ya göre gerçekleştirilecektir. Boşluk bulunan hallerde ise CMK’nın diğer hükümleri de kıyasen uygulanabilir. Kanun yolu başvuru hakkı verilmemiş olsa da ilgilisi açısından herhangi bir hak veya yükümlülük doğuran savcılık işlem ve kararlarının da ilgilisine bildirilmesi hukuk devleti ve hukuki dinlenilme hakkının gereğidir. ${ }^{59}$

\section{KARARIN, ALEYHINE KANUN YOLUNA BAŞVURULABILECEK KARARLARDAN OLMASI}

Md. 35/2'in düzenlemesine göre tebliğ edilmesi gereken kararın, aleyhine kanun yoluna başvurulabilecek bir hakim veya mahkeme kararı olması gerekmektedir. İlgilinin huzurunda verilmemiş olan bir karara karşı kanun yoluna başvurulabilmesi için karardan haberdar olunması,

58 Yargitay CGK, E 2016/11-1421 K 2020/461, 17.11.2020.

59 Savc1 kararlarının bildirilmesi konusunda bkz. Baytaz (n 9) $194 \mathrm{vd}$. 
bunun için de kararın tebliğ edilmesi gerekir. Diğer taraftan kanun yolu başvuru süresi hazır bulunan ilgilisine tefhim, bulunmayan ilgilisine ise tebliğ üzerine işlemeye başlayacaktır. Bu husus istinaf (md. 273/2) ve temyiz (md. 291/2) kanun yolu başvuru süreleriyle ilgili olarak CMK'da açıkça belirtilmiştir. Kanun yolu başvuru süresinin başlayabilmesi için de kararın hazır bulunmayan ilgilisine tebliği gerekir. ${ }^{60}$ Temyiz kanun yolu başvuru hakkı bulunanın kararı öğrenmesi sağlanmadan temyiz incelemesi yapılamaz. ${ }^{61}$

Diğer taraftan kanunda bazı kararların ilgilisine tebliğ edilmeyeceğine ilişkin özel düzenlemelere de yer verilmiştir. Örneğin, katılmadan önce verilmiş olan kararlar katılana tebliğ edilmeyecektir (md. 241/1). Söz konusu düzenlemeler md. 35/2 karşısında özel hüküm niteliğinde olduğu için öncelikle uygulama alanı bulacaktır. Yine CMK’nın çeşitli maddelerinde kararlar dışındaki bazı muhakeme işlemlerinin ilgilisine tebliğine ilişkin düzenlemelere de yer verilmiştir. ${ }^{62}$ Ancak yukarıda belirtildiği üzere md. 35, kararların bildirilmesine ilişkin genel bir düzenleme olduğundan, söz konusu tebliğler için doğrudan uygulanması söz konusu olmayacaktır.

Kanun yolundan neyin anlaşılması gerektiği ve hangi kararlara karşı kanun yoluna başvurulabileceği hususunun öncelikle CMK'ya göre belirlenmesi gerekir. Kanun yolundan neyin anlaşılması gerektiği kanunda tanımlanmamış, ancak hangi kararlara karşı hangi kanun yollarına başvurulabileceği kanunda gösterilmiştir. CMK’da, itiraz (md. $67 \mathrm{vd}$.), istinaf (md. $272 \mathrm{vd}$.) ve temyiz (md. $286 \mathrm{vd}$.) olağan kanun yolları, Yargıtay Cumhuriyet Başsavcısının itirazı (md. 308), bölge adliye mahkemesi Cumhuriyet başsavcılı̆̆ının itirazı (md. 308/A), kanun yararına bozma (md. 309) ve yargılamanın yenilenmesi (md. $311 \mathrm{vd}$.) ise olağanüstü kanun yolları olarak düzenlenmiştir. Kanaatimizce olağan kanun yolları yanında söz konusu olağanüstü kanun yolları da md. 35/2 kapsamında değerlendirilmelidir. ${ }^{63} \mathrm{Bu}$ nedenle kesin nitelikte olduğu için olağan kanun yolu başvuru imkanı bulunmayan ilk derece mahkemeleri, bölge adliye mahkemeleri ve Yargıtay kararları da hazır bulunmayan ilgilisine tebliğ edilmelidir. ${ }^{64}$ Buna karşın ceza mahkemesince verilen bir karara karşı diğer kanunlara göre başvuru imkanı olması halinde md. 35 kapsamında kararın tebliğinin zorunlu olup olmadığı tartışmaya açıktır. Örneğin, aleyhine AYM veya AİHM’ye bireysel başvuru yapılabilecek kararların tebliğinin de madde kapsamında olup olmadığı üzerinde durmak gerekir. Alman hukukunda sadece ceza muhakemesinde söz konusu olan sürelerin Alman CMK $\$ 35 / 2$ kapsamında olduğu, aleyhine Alman Anayasa Mahkemesine (AYM) veya AİHM’ye başvuru süreleri

60 Huzurunda verilmemiş bir karardan haberdar olan ilgilinin karar kendisine tebliğ edilmeden yapmış olduğu kanun yolu başvurusu da kanaatimce geçerli olup, tebliğin beklenmesi gerekli değildir. Çünkü tebliğ ile getirilen süre başvuru hakkının kullanılmasının başlangıcını değil son kullanma tarihini göstermek içindir.

61 CGK, E 2017/4-931 K 2020/173: 12.03.2020: "Yerel Mahkemece katılana gerekçeli karar tebliğ olunmamış ise temyiz aşamasında bu eksikliğin, Özel Dairece 2797 Sayılı Yargıtay Kanunu’nun 40. maddesi uyarınca verilecek, uygulamada 'tevdi kararı' adı verilen kararla mahallinde mahkemesince giderilmesinin istenilmesi gerekir; yoksa temyiz incelemesine geçilerek bozma kararı verilmek suretiyle bu eksiklik giderilemez. Aksi hâlde temyiz kanun yoluna başvuru hakkı bulunan bir tarafın kararı öğrenmesi sağlanmadan temyiz incelemesi yapılmış olur ve aleyhe temyiz bulunmayan hâllerde bozulan hükümdeki ceza miktarı sanık lehine kazanılmış hak teşkil eder."

62 Örneğin, md. 176/1, 277/1, 297/1, 297/3, 307/2.

63 Aynı görüşte, Baytaz (n 9) 188.

64 Ara kararlar ve ara kararlara yapılan itiraz üzerine merciin verdiği kararların da ilgilisine bildirilmesi gerekir. Bkz. Baytaz (n 9) 190-193. 
söz konusu olan kararların bu madde kapsamında olmadığı, söz konusu karaların kanundaki tebliğ usulüne bağlı kalmaksızın bildirilmesinin, örneğin kararın bir suretinin mektupla gönderilmesinin, yeterli olacağı kabul edilmektedir. ${ }^{65}$

AİHM’ye başvuru süresinin başlaması için ihlale neden olan kararın iç hukukta kesinleşmesi gerekmektedir (AİHS md. 35/1). ${ }^{66} \mathrm{CMK}$ açısından kararların kesinleşmesi için ise ilgilisine tefhim veya tebliğ suretiyle bildirilmesi gerekecektir. Türk hukuku açısından AYM’ye başvuru yapılabilmesi için ilgili kişinin mahkeme veya hakimlik kararını öğrenmiş olması yeterli olup, kararın tebliğ edilmiş olması zorunlu değildir. Çünkü 6216 sayılı Anaysa Mahkemesinin Kuruluşu ve Yargılama Usulleri Hakkında Kanunun 47. maddesinin 5. fikrasına göre, bireysel başvuru, başvuru yollarının tüketildiği tarihten; başvuru yolu öngörülmemişse ihlalin öğrenildiği tarihten itibaren otuz gün içinde yapılması gerekir. Bu düzenleme uyarınca bireysel başvuru süresi de tebliğden itibaren değil ihlalin öğrenilmesinden itibaren başlamaktadır. ${ }^{67}$ Ancak kararların bildirilmesi adil yargılanma hakkının kullanılmasına hizmet ettiği için aleyhine bireysel başvuru yapılabilecek hakim veya mahkeme kararları da ilgilisine tebliğ veya başka bir surette bildirilmelidir.

Md. 35/2 düzenlemesi ile ilgili tartışmaya açık bir başka konu da sadece "kanun yoluna başvurulabilecek” olan kararların tebliğinin zorunlu kılınmış olmasıdır. Halbuki CMUK md. 33/2'de, "Diğer kararlar tebliğ olunur." denilerek, ilgilinin huzurunda verilmemiş bütün kararların tebliği öngörülmüştü. Kaynak Alman CMK'da ilgilinin huzurunda verilmeyen bütün kararların ilgilisine bildirilmesi zorunluluğu kabul edilmiştir. Çünkü $\$$ 35/2’ye göre, ilgilinin huzurunda verilmemiş olan kararlardan, bildirilmesi bir süreyi başlatanların ilgilisine tebliğ suretiyle bildirilmesi zorunlu olup, süre başlatmayan kararların ise şekle bağlı olmayan tebliğ dışındaki bir yolla bildirilmesi yeterlidir. ${ }^{68} \mathrm{Bu}$ düzenlemeye göre, bildirilmesi herhangi bir süreyi başlatmasa bile karar suretinin mektup ile ilgilisine gönderilmesi veya tebliğ dışında başka bir şekilde kararın ilgilisine bildirilmesi gerekmektedir. ${ }^{69}$

CMK md. 35/2 hükmünün, CMUK md. 33/2 ve kaynak Alman CMK \$ 35/2'den ayrılan düzenlemesi isabetli olmamıştır. ${ }^{70}$ Aleyhine kanun yoluna başvurulması söz konusu olmasa bile görülmekte

65 Valerius (n 13) StPO $\$ 35$ Kn. 28; Wesslau (n 8) StPO $\$ 35$ Kn. 17, 19.

66 AİHS md. 35/1: "Mahkeme’ye ancak, uluslararası hukukun genel olarak kabul edilen ilkeleri uyarınca iç hukuk yollarının tüketilmesinden sonra ve iç hukuktaki kesin karar tarihinden itibaren dört aylk bir süre içinde başvurulabilir."

67 AYM, Başvuru Numarası: 2019/6266, 15.01.2020: "23. Bireysel başvuru süresinin işlemeye başlaması yönünden nihai kararın gerekçesinin tebliği, öğrenme şekillerinden biridir (Mehmet Ali Kurtuldu, B. No: 2013/5504, 28/5/2014, \$27). Ancak öğrenme, gerekçeli kararın tebliği ile sinırl olarak gerçekleşmez; başka şekillerde de öğrenme söz konusu olabilir. Başvurucunun nihai kararın gerekçesini dava dosyasını incelemek suretiyle ögrenmesi mümkündür. Bu doğrultuda dosyadan suret alıması gibi hâllerde başvurucunun gerekçeli kararı öğrendiği kabul edilebilir. Başvurucularm nihai kararın gerekçesini öğrendiklerini beyan ettikleri tarih de bireysel başvuru süresinin başlangıcı olarak ele alınabilir (İlyas Türedi, B. No: 2013/1267, 13/6/2013, \$\$ 21, 22)."

68 Bu açıdan Baytaz’ın (n 9, 174), "Alman hukukunda herhangi bir stmırlama olmaksızın, tefhim edilmeyen tüm kararların tebliğ edileceği AlmCMK’nun 35. maddesinin 2. fikrasında kaleme alınmıştır.” tespiti yerinde değildir.

69 Maul (n 8) StPO $\$ 35$ Kn. 18.

70 Md. 35/2 düzenlemesinin Hükümet Tasarısındaki şekli ve komisyonlarda yapılan değişiklikler hakkında bkz. Şahin, s. 152. Şahin’in açılklamalarına göre, 35. maddenin ikinci fikrası Adalet Komisyonunda değişikliğe uğramıştır. "Bu fikra Alt Komisyonda, Hükümet Tasarısındaki şekliyle kabul edilmişti. Hükümet Tasarısında ise fikra şu șekilde idi: 'Diğer kararlar 
olan davanın gidişatına ilişkin verilen kararlardan ilgilisinin haberdar olmasında haklı menfaati bulunabilir. Örneğin, md. 196/1 uyarınca duruşmada hazır bulunmaktan bağışık tutulma talebinde bulunan sanığın bu talebinin mahkemece kabul edilmemesi halinde bu karara karşı kanun yolu bulunmamakla birlikte bilgi sahibi olması için sanığa tebliğ edilmesi gerekir. Hem adil yargılanma hakkının gereği hem de verilen karar ile elde edilecek hakkın veya uğranacak mahrumiyetin bilinmesi açısından her türlü mahkeme ve hakim kararlarının verildiği sırada hazır olmayan ilgilisine tebliğ veya başka bir şekilde bildirilmesi gerekir. Bu bildirimin mutlaka tebliğ yoluyla olması geremez ise de tebliğ dışında nasıl bir yolla bildirileceğinin md. 35’te gösterilmesi gerekirdi. Teknolojinin ceza muhakemesi işlemlerinde de yoğun bir şekilde kullanılmasıyla birlikte hakim veya mahkeme kararlarının ilgilisine tebligat dışında kısa mesaj, e-posta, UYAP sistemi gibi bir çok şekilde çok kolay bir usulle bildirilmesi imkanı bulunmaktadır. Kanun yolu başvuru imkanı bulunup bulunmadığına bakılmaksızın yokluğunda verilen bütün hakim ve mahkeme kararların ilgilisine bildirilmesi hukuk devleti ve hukuki dinlenilme hakkının gereğidir. Bu nedenle CMK md. 35/2 hükmünün ilgilinin huzurunda verilmeyen bütün hakim ve mahkeme kararlarının ilgilisine bildirilmesi zorunluluğu içerecek şekilde yeniden düzenlenmesi isabetli olacaktır. ${ }^{71}$

\section{KARARIN, KORUMA TEDBIRLERINE ILIŞKIN OLMAMASI}

İlgilinin huzurunda verilmemiş olan kararların tebliği zorunluluğu için bir koşul daha kabul edilmiştir. Md. 35/2'ye göre, ilgilinin huzurunda verilmemiş bir kararın tebliği için koruma tedbirlerine ilişkin bir karar olmaması gerekmektedir. CMUK md. 33’te yer almayan bu düzenleme ilk bakışta gerekli gibi görünmektedir. Çünkü koruma tedbirlerinin niteliği gereği amacına ulaşabilmesi için kural olarak gizli kalması gerekir. Kararın icra edilmeden ilgilisine bildirilmesi tedbirin amacını tehlikeye düşürebilir. ${ }^{72}$ Kanunda bazı koruma tedbirlerine ilişkin işlem ve kararların gizliliğine yönelik özel düzenlemelere yer verilmiştir. Örneğin, telekomünikasyon yoluyla iletişimin denetlenmesine (md. 137/5) ve gizli soruşturmacı görevlendirilmesine ilişkin (md. 139/3) karar ve işlemlerin gizli tutulacağı Kanunda açıkça düzenlenmiştir. ${ }^{73}$ Söz konusu hükümler, md. 35/2'ye göre öncelikle uygulanacaktır.

Md. 35/2'nin açık düzenlemesi karşısında niteliği itibariyle gizli olsun veya olmasın koruma tedbirlerine ilişkin hakim veya mahkeme kararları, kararın verilmesi sırasında hazır bulunmayan ilgilisine tebliğ edilmeyecektir. ${ }^{74}$ Ancak koruma tedbirlerine ilişkin de olsa yapılan işlemler ve

tebliğ olunur.' Buna karşılık, 'Tebligat usulleri' başlıklı 37. Maddeye Alt Komisyonda, 'Yokluklarında verilen her türlü karar, sanık ve müdafiine ayrı ayrı tebliğ edilir' şeklinde eklenen 2. fikranın Adalet Komisyonu görüşmeleri sırasında 37. maddeden çıkarılması gündeme gelince, 37. maddenin yeniden düzenlenmesi uygun bulunmuştur." Yeniden düzenlenen 35. Maddenin 2. fikrası ise, "Koruma tedbirlerine ilişkin olanlar hariç, aleyhine kanun yoluna başvurulabilecek hakim veya mahkeme kararları, hukuken geçerli mazerete dayanarak hazır bulanamayan ilgilisine tebliğ olunur." şeklinde ifade edilmiştir. Kanaatimizce bu yeni düzenlemedeki hatayı gören kanun koyucu 5353 sayılı Kanun ile de fikra hükmünü bu günkü şeklinde değiştirmiştir. Aslında CMUK md. 33/2'yi esas alan Hükümet Tasarısındaki düzenlemenin isabetli olduğu anlaşılmaktadır.

71 Aynı yönde Baytaz (n 9) 188.

72 Güneş Okuyucu Ergün, Ceza Muhakemesi İşlemleri, (Yetkin 2015) 88.

73 Şahin ve Göktürk (n 1) 152.

74 Cumhur Şahin, Ceza Muhakemesi Kanunu Gazi Şerhi, (Adalet 2005) 152. 
verilen karardan etkilenenlerin kanun yollarına veya diğer hukuki çarelere başvurabilmeleri için bu kararların da usulüne uygun olarak ilgilisine bildirilmesi gerekir. Birçok koruma tedbirine karşı itiraz kanun yoluna başvurma hakkı bulunmaktadır. Örneğin, md. 104/2 uyarınca, "Şüpheli veya sanığın tutukluluk hâlinin devamına veya salıverilmesine hâkim veya mahkemece karar verilir. $\mathrm{Bu}$ kararlara itiraz edilebilir." Md. 108/1 uyarınca soruşturma evresinde söz konusu kararlar şüpheli veya müdafi dinlenmek suretiyle verileceği için çoğunlukla karar şüpheli veya müdafin huzurunda verilecektir. Ancak kovuşturma evresinde sanığın tutukluluk halinin devam edip etmeyeceği kararı verilirken md. 108/3’te sanık veya müdafiin dinlenmesi zorunluluğu öngörülmemiştir. Tutukluluğun devamına ilişkin karar şüpheli veya sanığın huzurunda verilmemişse, itiraz hakkının kullanabilmesi için kararın ilgilisine bildirilmesi gerekir. Ancak söz konusu karar koruma tedbirlerine ilişkin olduğu için md. 35/2 uyarınca ilgilisine bildirilmeyecek kararlar kapsamına girmektedir.

Md. 35/2'deki koruma tedbirlerine ilişkin hakim ve mahkeme kararlarının ilgilisine tebliğ edilmeyecek olması bu kararların ilgilisine bildirilmeyeceği anlamına gelmez. Çünkü md. 36/2 uyarınca infazı gereken hakim veya mahkeme kararları gereği yerine getirilmek üzere Cumhuriyet savcılığına verilecek ve kararın tebliğ veya başka bir şekilde ilgilisine bildirilmesi de savcılık tarafından yerine getirilecektir. Ancak sadece infazı gereken kararlar Cumhuriyet savcılığına verilecek olup ilgilisine bildirilmesi de ancak bu kararlar için söz konusu olacaktır. Koruma tedbirlerine ilişkin kararların çoğunluğunun infazı gereken kararlardan olduğu söylenebilir. Diğer taraftan md. 104/2'de olduğu gibi savcllık tarafından infazı gerekmeyen koruma tedbirine ilişkin hakim ve mahkeme kararları da söz konusu olabilir.

Md. 35/2'deki söz konusu sınırlama olmasaydı da koruma tedbirlerine ilişkin olup da gizli kalması gereken kararların ilgilisine tebliğ edilmeyip savcllığa verilmesi md. 36/2 düzenlemesinin bir sonucudur. Ancak md. 35/2 düzenlemesi ile koruma tedbirlerine ilişkin bütün kararlar açısından tebliğ yasağı getirilmesi gerekli olmadığı gibi, md. 104/2'e göre verilen kararlar da olduğu gibi, infazı gerekmeyen kararlar açısından da isabetli değildir.

\section{KARARIN VERILDIĞi SIRADA ILGILININ HAZIR BULUNAMAMIŞ OLMASI}

Tebliğ zorunluluğu için aranan bir diğer koşul, kararın verildiği sırada ilgilinin hazır bulunamamış olmasıdır. Madde metninde bu husus karar, "hazır bulunamayan ilgilisine tebliğ olunur" denilerek belirtilmiştir. 25.05.2005 tarihli ve 5353 sayılı Kanunun ile md. 35/2'de önemli bir değişiklik yapılmıştır. Değişiklikten önce kararların tebliği için ilgilinin hazır bulunmamasının hukuken geçerli bir mazerete dayanması gerekmekteydi. Bu düzenlemenin kanun yoluna başvuru hakkının kullanılmasını engelleyebileceğini fark eden kanun koyucu, fikrada geçen "hukuken geçerli mazerete dayanarak" ibaresini madde metninden çıarmıştır. ${ }^{75}$ Doktrinde, değişiklikten sonra da "hazır bulunamayan" ibaresinden hareketle duruşmada hazır bulunamamanın geçerli bir mazerete dayanması gerektiği ileri sürülmüştür. ${ }^{76}$ Kanaatimizce ilgilinin hazır bulunamamış olması yeterli

75 Değişiklik ile ayrıca "bulanamayan" kelimesi dede "bulunamayan" olarak değiştirilerek yazım hatası düzeltilmiştir.

76 Özbek, Doğan ve Bacaksız (n 3) 138. 
olup, bunun için herhangi bir mazeret bildirilmesi gerekli değildir. Çünkü değişikliğin amacı mazeret gösterilmesini kaldırmaktır. Ancak tartışmaya mahal vermemek açısından "bulunamayan" ibaresi yerine "bulunmayan" ibaresine yer verilmesi isabetli olurdu. Nitekim, kaynak Alman CMK md. 35/2'yi dikkate alan CMUK md. 33/2'de, maddenin birinci paragrafı ile bağlantıll şekilde, "Diğer kararlar tebliğ olunur." denilerek, ilgilinin yüzüne karşı verilmeyen bütün kararların tebliğ edileceği belirtilmiş, "hazır bulunamayan" şeklinde tartışmaya neden olacak bir ibareye yer verilmemişti. Aslında hem 35. Maddenin 1. Fikrasında hem de 2. fikrasında kastedilen, karar verilirken ilginin hazır bulunup bulunmaması, diğer bir ifade ile kararın ilgilinin huzurunda verilmiş olup olmamasıdır. ${ }^{77}$ Maddenin 2. fikrasında "diğer kararlar" veya" ilginin huzurunda verilmeyen kararlar" şeklinde bir ifade isabetli olurdu.

Diğer taraftan ilgili kişi veya Cumhuriyet savcısının yüzüne karşı verilen hüküm kısa karar niteliğinde ise, yani hüküm, hazır bulunan ilgilisine gerekçesiyle birlikte açıklanmamışsa, gerekçeli hükmün kanun yoluna başvuranlara ayrıca tebliğ edilmesi gerekir (md. 275/2).

\section{E. KARARIN VERILDIĞi SIRADA HAZIR BULUNAMAYAN KIŞININ SERBEST OLMAMASI VEYA TUTUKLU OLMASI HALINDE TEBLIGATA ILIŞKIN ÖZEL DÜZENLEME}

Md. 35/3’te serbest olmayan kişi veya tutukluya tebligata ilişkin özel bir düzenleme yapılmıştır. Buna göre, kararın verildiği sırada hazır bulunamayan kişi tutuklu veya özgürlüğü başka şekilde kısıtlanmış bir kişi ise tebliğ edilen karar, kendisine okunup anlatılacaktır. CMUK md. 33/2'de sadece tutukluya tebliğ edilen kararın okunup anlatılması kabul edilmişti. Yeni düzenlemede tutukluluk dışındaki başka sebeplerle özgürlüğü kısıtlanmış kişiler için de aynı usul kabul edilerek söz konusu boşluk giderilmiştir. ${ }^{78}$ Ancak tutuklu kişi de serbest olmayan kişi olduğu için madde metninde ayrıca tutuklu kişiden bahsedilmesine gerek bulunmamaktadır. Nitekim kaynak Alman CMK'da sadece “serbest olmayan kişiye" tebliğ edilen belgenin okunacağı belirtilmektedir $(\$ 35 / 3)$.

CMK md. 35 gerekçesinde, "serbest olmayan bir kişiden maksat, Kanunun öngördüğ̈̈ işlemler çerçevesinde yakalanmış, gözaltına alınmış veya bu maksatla bir yerden başka bir yere götürülmekte olan kişinin durumu" açıklamasına yer verilerek, CMK uyarınca gerçekleştirilen bazı özgürlük kısıtlamalarına işaret edilmiştir. Ancak gerekçedeki bu açıklama isabetli değildir. Çünkü, hakkında hükmedilmiş ceza infaz edilen kişi de serbest olmayan kişidir. Yine tutuklama, yakalama ve gözaltına alma dışındaki CMK'da öngörülen diğer özgürlük kısıtlamaları, örneğin, tanıklar hakkında uygulanan disiplin hapsi, şüpheli veya sanığın gözlem altına alınması gibi tedbirler teknik anlamda bir yakalama veya gözaltına alma olmamakla birlikte, hakkında söz konusu işlemler uygulanan kişiler de md. 35/3 anlamında serbest olmayan kişidir. Diğer taraftan CMK dışındaki diğer kanunlara dayanılarak mahkemeler veya kamu makamlarınca gerçekleştirilen özgürlük kısıtlamaları da kanaatimizce madde kapsamındadır. Örneğin, İcra İflas Kanunu hükümleri uyarınca uygulanan disiplin ve tazyik hapsi nedeniyle özgürlüğü kısıtlanan kişiler de CMK md. 35/3 anlamında serbest olmayan kişi olarak kabul

77 Ayrıca bkz. md. 231/2.

78 Özbek, Doğan ve Bacaksız (n 3) 138. 
edilmelidir. Kanaatimizce serbest olmamaktan maksat, sadece yakalama, gözaltına alma, tutuklama ve hükümlülük hali ile sınırlı olmayıp, hakim veya diğer kamu mercilerince gerçekleştirilen her türlü özgürlük kısıtlaması şeklinde anlaşılmalıdır. ${ }^{79} \mathrm{Bu}$ nedenle sadece yakalanan, gözaltına alınan veya tutuklanan kişilere değil, CMK veya diğer kanunlar uyarınca kamu mercilerinin kararları ile özgürlüğü kısıtlanmış ve devletin gözetim ve denetimi altında olan diğer kişilere yapılacak tebligat için de madde 35/3 hükmü uygulama alanı bulmalıdır.

Kararın, serbest olmayan veya tutuklu olan ilgilisinin yokluğunda verilmesi nedeniyle tebliği gereken durumlarda, md. 35/3 uyarınca karar ayrıca ilgilisine okunup anlatılmalıdır. Bu nedenle cezaevinde tutuklu olan kişiye kararın sadece tebliği yeterli olmayıp, kararın ayrıca kendisine okunup anlatılması da gerekmektedir. Yargıtay isabetli olarak tebliğe ilişkin belgede, kararın "okunup anlatılmak" suretiyle tebliğ edildiğine ilişkin bir ibare bulunmaması halinde, yapılan tebligat işleminin usulsüz olduğuna karar vermiştir. ${ }^{80}$ Yine infaz kurumundaki hükümlüye tebliğ edilecek kararın sadece okunması yeterli olmayıp, içeriğinin, anlayacağı şekilde hükümlüye anlatılması gerekir. ${ }^{81}$ Ancak md. 35/3 açısından dikkat edilmesi gereken husus, bu hükmün serbest olmayan kişinin yokluğunda verilen kararlar açısından uygulama alanı bulmasıdır. Bu nedenle, sanık veya müdafinin yüzüne karşı verilen kararın kendisine açıkça anlatılması ve karara karşı başvurulabilecek kanun yolunun, süresinin, mercii ile şeklinin belirtilmiş olması halinde, gerekçeli kararın tebliğ edildiği tarihte infaz kurumunda tutuklu bulunan sanığa yapılacak tebliğ sırasında artık md. 35/3 uyarınca kararın okunup anlatılması gerekmez. Yargitay da yerinde olarak, “... sanık ve müdafisine yapılan tefhimde, verilen kararın açıç̧a okunup usulen anlatılması, karara karşı başvurulacak kanun yolunun, süresinin, mercisinin ve şekillerinin belirtilmiş olması ile birlikte gerekçeli kararın tebliğinin usulsüz olduğuna dair bir itirazın da bulunmaması karşısında; gerekçeli kararın kendisine tebliğ edildiği tarihte ceza infaz kurumunda tutuklu bulunan sanığa isteği üzerine gerekçeli karar tebliğ edilirken CMK’nın 35. maddesinin üçüncü fikrası uyarınca bu kararın okunup anlatılmasının gerekmediği, bu yöndeki uygulamanın İHAS'ın 6. maddesinde yer alan adil yargılanma hakkı ile Anayasa'nın 36 ve 40. maddelerinde güvence altına alınan temel hak ve hürriyetleri ihlal etmediği, dolayısıyla sanı̆ga 'okumak/almak' suretiyle yapılan tebliğin usule uygun olduğu kabul edilmelidir." şeklinde karar vermiştir. ${ }^{82}$

Diğer taraftan kararın serbest olmayan kişiye sadece okunup anlatılması da tebliğ yerine geçmez. Çünkü md. 35/3 hükmü, md. 35/2'deki tebliğ işlemini tamamlayıcı bir hükümdür. Bu nedenle tebliğ evrakı okunup anlatılmadan önce kararın ilgili kişiye usulüne uygun bir şekilde tebliğ edilmesi de gerekir. Kararın okunup anlatılması yükümlülüğünün yerine getirilmemiş ve bu nedenle kanun yolu başvuru süresinin geçirilmiş olması ilgili kişi açısından eski hale getirme nedeni oluşturacaktır. ${ }^{83}$

79 Maul (n 8) StPO $\$ 35$ Kn. 20; Wesslau (n 8), StPO $\$ 35$ Kn. 21.

80 CGK, E 2017/20-819 K 2019/700, 10.12.2019.

81 Yargıtay 6. CD, E 2014/10490 K 2018/397, 16.01.2018: "hükümlüye cezaevi aracıllğı ile 30.07.2013 tarihinde gerekçeli karar tebliğ edilmiş ise de 5271 Sayıl CMK’nın 35/3. maddesi uyarınca tebliğ tarihinde serbest olmayan hükümlüye kararın okunup anlatılması gerekirken sadece okunup tebliğ edilmesi ile yetinildiği bu durumda yapılan tebligatın geçersiz olduğu".

82 CGK, 10.10.2019, E 2019/9-355 K 2019/59; aynı yönde CGK, 01.10.2019, E 2019/9-460 K 2019/572.

83 Maul (n 8) StPO $₫ 35$ Kn. 20; Valerius (n 13) StPO $₫ 35$ Kn. 30; Larcher (n 16) StPO $\$ 35$ Kn. 18. Eski hale getirmenin koşulları ve usulü hakkında ayrıntılı bilgi için bkz. Turhan (n 37) $1227 \mathrm{vd}$. 
Tebliğ edilen evrakın okunup anlatılması görevi, tebligatı yapan görevli veya ilgilinin bulunduğu kurumun bir görevlisi tarafından yapılır. Gerektiğinde, kararı tebliğ edilecek mahkeme, mahkemenin zabıt katibini bu işle görevlendirebilir. ${ }^{84}$

Okunup anlatılma ihtiyacı özellikle okuma yazma bilmeyen veya görme engelli kişi açısından önem taşıyacaktır. Yine avukatı veya müdafii olmayan veya ulaşmakta güçlük çeken tutuklu veya hükümlünün tebliğ edilen kararın içeriği ve başvuru yolları hakkında bilgilenme ihtiyacı olabilecektir. Kanunun emredici hükmü karşısında ilgili kişinin tebliğ edilecek kararın okunup anlatılmasını istemesi gerekli değildir. Ancak duruma göre yüzlerce sayfadan oluşan bir mahkeme kararının okuma yazma bilen bir tutukluya talebini aramaksızın okunması gerçekçi olmadığı gibi, uygulamada yoğun iş yükü altında olan infaz kurumu görevlilerince yerine getirilmesini beklemek de doğru değildir. Madde metnindeki, "okunup anlatılır" ifadesi de karar metninin aynen okunmasindan ziyade ilgili kişinin karar içeriği hakkında anlayacağ ş̧ekilde bilgilendirilmesine işaret etmektedir. Madde metninde okuma zorunluluğu yerine böyle bir hakkı olduğunun kişiye bildirilmesine ilişkin bir düzenleme yerinde olurdu. Nitekim kaynak Alman CMK $₫ 35 / 3$ ’te ilgili kişinin isteği halinde kendisine okunması kabul edilmiştir.

\section{KARARLARIN TEBLIĞi VE INFAZI GEREKEN KARARLARIN CUMHURIYET BAŞSAVCILIĞINA VERILMESI}

Kararların tebliği ve yerine getirilmesinde yetki konusu md. 36'da düzenlenmektedir. Md. 36 fik. 1'de kararların tebliğine mahkeme başkanının karar vereceği, fik. 2'de ise infazı gereken kararların Cumhuriyet başsavcılığına verilerek savcılık tarafından infazının yapılacağı belirtilmiştir. Madde metninden ve önceki maddelerin düzenlemesinden anlaşılacağı üzere burada söz konusu olan yine hakimlik ve mahkeme kararlarıdır. Savcllık kararlarının tebliği CMK'da düzenlenmemiş olup, söz konusu kararların tebliğ ve infazı başsavcılık tarafından geçekleştirilecektir. ${ }^{85}$

\section{A. MAHKEME BAŞKANI VEYA HAKIMIN TEBLIĞE KARAR VERMESI VE TEBLIĞiN YERINE GETIRILMESI}

İlgilinin huzurunda verilmeyen kararların tebliği, heyet halinde çalışan mahkemelerde mahkeme başkanının, tek hakimli mahkemelerde ise hakimin kararı ile gerçekleştirilecektir. CMUK md. 34 'te, mahkemelerce verilen kararların tebliğinin Cumhuriyet savcıllğı tarafından yapılması kabul edilmişti. Tebligatların savcılık tarafından yapılmasına ilişkin bu düzenleme tebligatlarda gecikmeye ve yargının işleyişinde yavaşlamaya neden olmaktayd.$^{86} \mathrm{CMK}$ 'da bu konuda önemli bir değişikliğe gidilmiş, hakim veya mahkemelerin kendi kararlarının tebliğlerinin kendileri tarafından yapılması kabul edilerek yargının işleyişi hızlandırılmak istenmiştir.

84 Valerius (n 13) StPO $\$ 35$ Kn. 31.

85 Meyer-Gossner (n 25) StPO $\$ 36$ Kn. 11.

86 Ünver ve Hakeri (n 2) 146. 
Mahkeme başkanı ve hakim yanında naip hakim, istinabe olunan hakim ve sulh ceza hakimi de verdikleri kararlardan tebliği gerekenlerin tebliğini sağlama görev ve yetkisine sahiptir. ${ }^{87}$ Ancak aşağıda inceleneceği üzere soruşturma evresindeki sulh ceza hakimi kararları çoğunlukla koruma tedbirlerine ilişkin ve infazı gereken kararlardan olduğundan bu kararların infazı için Cumhuriyet savcılığına verilmesi gerekecektir.

Mahkeme ve hakimlerin tebligata ilişkin yetki ve görevleri md. 36/1'de, "Mahkeme başkanı veya hakim, her türlü tebligatı, tüm gerçek veya özel hukuk tüzel kişileri veya kamu kurum ve kuruluşları ile ilgili yazışmaları yapar.” denilerek, tebligat ve yazışmaların mahkeme başkanı veya hakim tarafından bizzat yapılacağı gibi yanlış anlamaya neden olacak bir ifade kullanılmıştır. Söz konusu yazışmaları yapmak ve tebligat evrakını hazırlamak mahkeme başkanı veya hakimin değil, zabıt katibinin görevidir. ${ }^{88}$ Madde metninde düzenlenmek istenen husus, tebligata, heyet halinde görev yapan mahkemelerde mahkeme başkanının, tek hakimli mahkemelerde hakimin karar vereceği ve tebligatın ancak bu karar üzerine yapılabileceğidir. Diğer bir ifade ile hangi kararların tebliğ edileceğine ve hangi kararların infazı için Cumhuriyet başsavcılığına verileceğine mahkeme başkanı veya hakim karar verecek, tebligat ile ilgili işlemleri ise mahkeme kalemi yerine getirecektir. ${ }^{89}$ Tebligat evrakının hazırlanması, tebligatı yerine getirecek görevliye verilmesi ve işlemlerin takibi, yazı işlerindeki görevliler tarafından yerine getirilecektir. Nitekim kaynak Alman CMK $\$ 36 / 1$ 'de, "Kararların tebliğine mahkeme başkanı karar verir. Mahkeme kalemi tebligatın yapılmasını sağlar" denilerek bu husus açıkça belirtilmiştir.

Mahkeme başkanının veya hakimin kararı olmadan yapılan tebligat geçerli değildir. ${ }^{90}$ Alman uygulamasında, başkanın tebligata ilişkin kararının yazılı olması gerektiği, sözlü emrin yeterli olmadığı, kararın her bir tebligat işlemi için ayrıca verilmesi gerektiği, başkanın tebligata ilişkin karar veya emri olmadan yapılan tebligatın geçerli olmayacağı kabul edilmektedir. Yine mahkeme başkanın tebligata ilişkin kararına aykırı olarak icra edilen tebligat (örneğin, kararda tebligatın müdafie yapılması yazılmışken, sanığa tebligat yapılması) geçerli bir tebligat işlemi olarak kabul edilememektedir. ${ }^{91}$

\section{B. INFAZI GEREKEN KARARLARIN CUMHURIYET BAŞSAVCILIĞINA VERILMESi}

Savcılığın tebligat ile ilgili görevi iki şekilde ortaya çıkmaktadır. Birincisi, savcılık, vermiş olduğu kararlarını tebliğini yine kendisi yapacaktır. ${ }^{92}$ Bu kapsamda soruşturma evresinde tebligat işlemleri soruşturmayı yürüten Cumhuriyet savcıları tarafından yapılacaktır. ${ }^{93}$ Tebligata ilişkin ikinci görevi ise, infazı gereken hakim veya mahkeme kararlarının savcılık tarafından ilgilisine bildirilmektir.

87 Maul (n 8) StPO \$ 36 Kn. 10; Valerius (n 13) StPO $\$ 36$ Kn. 4.

88 Yazı İşleri Yönetmeliği md. 105/3, f), 1).

89 Yenisey ve Nuhoğlu (n 2) 134.

90 ibid 134; Maul (n 8) StPO $\$ 36$ Kn. 3-4; Meyer-Gossner (n 25) StPO \$ 36 Kn. 2.

91 Maul (n 8) StPO $\$ 36$ Kn. 3-4; Meyer-Gossner (n 25) StPO $\$ 36$ Kn. 2-3; Valerius (n 13) StPO $\$ 36$ Kn. $10,12$.

92 Meyer-Gossner (n 25) StPO $\$ 36$ Kn. 11.

93 Mustafa Artuç, Açıklamalı Pratik Ceza Muhakemesi Kanunu (3. Bası, Seçkin 2019) 151. 
Yukarıda açıklandığı üzere infazı gereken kararlar için kanunda özel bir düzenleme yapılmıştır. Md. 36/2'ye göre, infazı gereken hakim veya mahkeme kararları tebliğ edilmeyip ilgili başsavcıllğa verilecek ve başsavcılık tarafından da gereği yerine getirilecektir. Kanun koyucu önceden yapılan tebligat ile kararın yerine getirilmesinin zarar görmesini önlemek için kararın bildirilmesi ve infazının aynı elde olmasını istemiştir. Ancak savcılığın tebliğ ile ilgili görevi sadece gerektiğinde zor kullanılarak icra edilmesi söz konusu olan tutuklama, arama ve elkoyma gibi hakim veya mahkeme kararları için söz konusudur. ${ }^{94}$

Bir kararın infazının gerekip gerekmediği infaz kavramının yorumuna bağlıdır. Kanunda kararı veren merciin kural olarak kararın tebliği ile ilgili işlemleri de yapması kabul edildiği için (md. 36/1), "infaz edilecek kararlar" kavramının dar yorumlanması gerekmektedir. Bu nedenle infaz kelimesi geniş anlamda yerine getirme (Ausführung) anlamında değil, kelime anlamında - günlük hayattaki kullanılışı anlamında - gerektiğinde zor kullanılarak icra etme (zwangsweise Durchsetzung) şeklinde anlaşılmalıdır. ${ }^{95}$

İnfazı gereken hakim veya mahkeme kararlarının çoğunluğu koruma tedbirlerine ilişkin olmakla birlikte diğer bazı kararların da bu kapsamda yer aldığı söylenebilir. Md. 36/2 anlamında infazı gereken kararlara örnek olarak şu kararlar verilebilir: ${ }^{96}$ Usulüne uygun olarak çağrilıp da mazeretini bildirmeksizin gelmeyen tanıkların zorla getirilmesi kararı (md. 44/1), yasal bir sebep olmaksızın tanıklıktan veya yeminden çekinen tanık hakkında tanıklığa veya yemine zorlamak için verilen disiplin hapsi kararı (md. 60) ${ }^{97}$, usulüne göre çağrıldığı halde mazeretsiz olarak gelmeyen veya gelip de görüş bildirmekten çekinen bilirkişi hakkında verilen disiplin hapsi kararı (md. 71, 60/1), şüpheli veya sanığın gözlem altına alınması kararı (md. 74), şüpheli veya sanığın beden muayenesi ve vücudundan örnek alınmasına (md. 77/1), diğer kişilerin beden muayenesi ve vücuttan örnek alınmasına (77/1) ilişkin kararlar, şüpheli veya sanık hakkında verilen yakalama emri (md. 98 fik. 1 ve 3), tutuklama ve adli kontrole ilişkin kararlar (özellikle md. 101/1, 110, 111/1, 112/1), arama ve elkoymaya ilişkin kararlar (md. 119/1, 127/1, 128/9, 129/1, 130/1, 133/1, 134/1), iletişimin tespiti, dinlenmesi ve kayda alınmasına (md. 135), gizli soruşturmacı görevlendirilmesine (md. 139), teknik araçlarla izlemeye (md. 140/2), zorla getirmeye (md. 146), duruşmada hazır bulunmayın sanığın zorla getirilmesine (md. 193/1) ve sanığın zorla getirilmesine (md. 199) ilişkin kararlar.

94 Meyer-Gossner (n 25) StPO $\$ 36$ Kn. 10; Maul (n 8) StPO $\$ 36$ Kn. 10.

95 Maul (n 8) StPO $\$ 36$ Kn. 11.

96 Valerius (n 13) StPO $\$ 36$ Kn. 16; Maul (n 8) StPO $\$ 36$ Kn. 12; StPO Meyer-Gossner (n 25) StPO $\$ 36$ Kn. 12.

97 Alman Federal Yüksek Mahkemeye göre, yasal bir sebep olmaksızın tanıklıktan çekinen tanığı tanıklı̆ga zorlamak için verilen disiplin hapsi kararının infazı sağlamak da kararı veren hakim veya mahkemenin yetkisindedir. Çünkü zorlama hapsine hükmeden hakimin verdiği kararın infazına engel bir durumun (örneğin, kendisi veya kanunda sayılan yakınlarını ceza kovuşturmasına uğratabilecek sorulara cevap vermekten kaçınma hakkı gibi) kararın infazı sırasında ortaya çıkıp çıkmadığı konusundaki kararın da bu hakim tarafından verilmesi gerekir. Ancak zorlama hapsinin savcı tarafından dinlenecek olan tanığa karşı sorgu hakimi tarafından verilmesi halinde ise kararın infazı ve ortaya çıkması muhtemel infaz engeli konusundaki yetki savcllğa aittir: Bkz. Federal Yüksek Mahkemenin 17.03.1989 ve I BGs 100/89 GBA - 1 BJs 72/87-4 sayll kararı (NJW 1989, 1740). 
Doktrinde, tutuklama kararının geri alınması (md. 103), adli kontrol kararının kaldırılması (md. 111) ve elkoymanın kaldırılması gibi koruma tedbirlerinin kaldırılmasına ilişkin kararların infazı gereken kararlar kapsamında yer almadığı belirtilmektedir. ${ }^{98}$

Kararın Cumhuriyet başsavcılığına verilmesinin amacı kararın infazı ve ilgiliye bildirilmesi olduğu için, md. 36/2'de açıkça belirtilmemiş olsa da, başsavcılık, kararın verilmesi üzerine kararın infazı ve tebliği için gerekeni yapacaktır. Nitekim kaynak Alman CMK'da bu husus, infazı gereken kararlar, "gereğinin ifası için savcilığa verilir" denilerek açıkça ifade edilmiştir ( $\$ 36 / 2)$. Kararın verileceği yetkili başsavcılık, mahkemenin yargı çevresinde bulunan başsavcılıktır. Ancak başsavcılık, gerektiğinde işlemin yapılmasını diğer bir başsavcılıktan talep edebilir. Cumhuriyet savcısının kararlarına karşı hakime başvurabilmeye ilişkin genel bir düzenlemeye kanunda yer verilmediği için başsavcılık tarafından kararın infazı ile ilgili başvurulan tedbirlere karşı ilgilinin itiraz hakkı ancak kanunda açıkça belirtilen hallerde mümkündür. ${ }^{99}$

Md. 36/2 hükmünün infazı gereken kesinleşmemiş hakim ve mahkeme kararları şeklinde anlaşılması gerekir. ${ }^{100}$ Çünkü infazı gereken kesinleşmiş mahkumiyet kararlarının savcıllğa bildirilmesi Cezaların ve Güvenlik Tedbirlerinin İnfazı Hakkında Kanunun 5. maddesinde özel olarak düzenlenmiştir. Bu hükme göre kesinleşen ve infazı gereken cezaya ilişkin mahkeme kararları Cumhuriyet başsavcıllğına gönderilir ve cezanın infazı da Cumhuriyet savcısı tarafından izlenir ve denetlenir.

Kaynak Alman CMK $\$ 36 / 2$ 'de, duruşmada düzenin sağlanması ile ilgili kararların savcılığa verilmeyeceği belirtilerek, infazı gereken kararların savcıllğa verilmesine ilişkin kurala bir istisna getirilmiştir. Bu hüküm uyarınca duruşmalarda düzenin sağlanmasına ${ }^{101}$ ilişkin kararların infazına ilişkin yetki mahkeme başkanına aittir. Alman Mahkemeler Teşkilat Kanunu § 179’a göre, mahkeme başkanı kanunda belirtilen hükümler uyarınca verilen kararların infazını bizzat emreder. ${ }^{102}$

CMK md. 36/2'de infazı gereken kararların başsavcıllğa verilmesi açısından herhangi bir istisnaya yer verilmemiş olsa da kaynak Alman kanununda olduğu gibi Türk hukukunda da duruşmanın düzen ve disiplini ile ilgili olarak hakim, mahkeme başkanı veya mahkemenin CMK md. 203204 uyarınca almış olduğu tedbir ve kararların infazı ile hususların da yine mahkemenin kendisi tarafından yapılması gerekir. Bu açıdan örneğin, davranışları ile duruşmanın düzenli bir şekilde yapılmasını engelleyen sanığın duruşma salondan çıkarılmasını emreden mahkeme başkanının bu emrinin infazını savcılığa bırakması yerinde olmayacaktır. Yine bu sanığın dışarı çıkarılmaya karşı koyması halinde disiplin hapsine konmasına ilişkin kararın yerine getirilmesi için gereğinin yapılmasını sağlamak da yine mahkeme başkanının yetkisinde olmalıdır. Söz konusu kararların yerine getirilmesi görevinin Cumhuriyet savcısına verilmesi mahkeme başkanının otoritesine aykırı

98 Valerius (n 13) StPO $\$ 36$ Kn. 17; Maul (n 8) StPO $\$ 36$ Kn. 13; Meyer-Gossner (n 25) StPO $₫ 36$ Kn. 12

99 Savcılık kararlarına karşı itiraz hakkı konusunda ayrıntılı bilgi için bkz. Hüseyin Şık, Türk Adli Yargı Sisteminde Savcılık Kurumu, (Adalet 2018) $381 \mathrm{vd}$.

100 Maul (n 8) StPO $\$ 36$ Kn. 10.

101 Alman Mahkemeler Teşkilat Kanunu $\$ 169 \mathrm{vd}$.

102 Valerius (n 13) StPO $\$ 36$ Kn. 21 
olacaktır. Bu hususlara ilişkin olarak Alman CMK $\$ 36 / 2$ 'deki gibi bir düzenlemeye CMK'da yer verilmesi yerinde olacaktır

\section{CUMHURIYET BAŞSAVCILIĞINA TEBLIGAT}

Cumhuriyet başsavcılı̆̆ına tebligatın nasıl yapılacağı md. 38'de düzenlenmiștir. Buna göre, "Cumhuriyet Başsavcılığına yapılan tebligat, tebliği gereken evrakın aslının verilmesi suretiyle olur. Tebliğ ile bir süre işlemeye başlıyorsa verildiği gün, Cumhuriyet Başsavcılı̆̆ı tarafından evrakın aslına yazılır." Kararın aslının Cumhuriyet başsavcılığına verildiği tarih, tebliğ tarihi sayılır. ${ }^{103}$ Evrakın aslının başsavcılığa verildiği günün evrak aslına yazılmasının nedeni başsavcılık tarafından kanun yoluna başvurulması halinde başvurunun zamanında yapılıp yapılmadığının tespitini sağlamaktır.

Ancak aynı konuya ilişkin TK md. 43’te farklı bir düzenleme yer almaktadır. Bu hükme göre, "Cumhuriyet Başsavcılığına yapılacak tebligat, tebliğ olunacak varaka aslının kendisine gösterilmesiyle olur. Bu tebliğ bir mehile başlangıç olacaksa, Cumhuriyet Müddeiumumisi gösterildiği günü varakanın aslına işaret ve imza eder." Her iki düzenleme arasındaki birinci ifade farkı, tebliğ olunacak evrakın aslının verilmesi açısından söz konusu olmaktadır. CMK’ya göre tebliği gereken evrakın aslı Cumhuriyet başsavcılığına verilmesi gerekirken, TK’ya göre ise evrak verilmeyip gösterilecektir. Düzenlemeler arasındaki ikinci fark ise, tebliğ ile bir süre işlemeye başlıyorsa, CMK’ya göre Cumhuriyet başsavcılığı tarafından evrakın verildiği günün evrak aslına yazılması, TK’ya göre ise Cumhuriyet savcısı tarafından gösterildiği günün evrakın aslına işaret edilip imza edilecek olması açısındandır. Yukarıda açıklandığı üzere savcının hazır bulunduğu sırada verilen kararlar yüzüne karşı verilmiş sayılacağı için bu kararların ayrıca savcılığa tebliğ amacıyla verilmesi söz konusu olmayacaktır.

CMK md. 38'in karşılığı olarak CMUK’ta herhangi bir düzenleme yer almamaktaydı. TK md. 43'teki mevcut düzenlemeye rağmen $\mathrm{CMK}$ md. 38'de niçin yeni ve farklı bir düzenleme yapıldığına ilişkin madde gerekçesinde bir açlklamaya yer verilmemiştir. Kanaatimizce evrak aslının verilmesi ya da gösterilmesi anlam olarak farklıklar içerse de işlemin yapılması ve sonuçları açısından farklı bir sonucu görünmemektedir. Aslında TK md. 43 hükmü karşısında CMK md. 38'de yeni bir düzenleme yapılmasına gerek bulunmuyordu. Sonuç itibariyle hem sonraki hüküm olarak hem de CMK uyarınca yapılacak tebligatlarda CMK'daki düzenlemelerin önceliği (md. 37/1) hükmü uyarınca CMK md. 38, TK md. 43 hükmü karşında öncelikle uygulanacaktır; ${ }^{104}$ ancak CMK dışındaki mevzuata göre başsavcılığa tebliği gereken karar ve işlemlerin (örneğin, MK’ya göre) ${ }^{105} \mathrm{TK}$ md. 43 hükmüne göre tebliğ edilmesine devam edilecektir.

103 Artuç (n 93) 155.

104 Aynı yönde bkz. Özbek, Doğan ve Bacaksız (n 3) 137.

105 Yargıtay 8. HD, E 2017/2479 K 2017/12285, 05.10.2017: “Davacı vekili dava dilekçesinde, 26.04.2013 doğumlu Eda’nın babasının davalı ... olduğunu ileri sürerek, babalığın tespitini istemiş; mahkemece davanın kabulüne karar verilmiştir. // 4721 Sayılı Türk Medeni Kanununun 301.maddesinde; "Çocuk ile baba arasındaki soybağının mahkemece belirlenmesini ana ve çocuk isteyebilirler. Dava babaya, baba ölmüşse mirasçılarına karşı açılır. Babalık davası, Cumhuriyet Savcısına ve Hazineye; dava ana tarafından açılmışsa kayyıma; kayyım tarafindan açılmışsa anaya ihbar edilir." hükümleri yer almaktadır. // Dosyadaki bilgi ve belgelerin incelenmesinden; Mahkeme kararını, Cumhuriyet Savcısina usulüne uygun 
Diğer taraftan UYAP vasıtasıyla yapılan işlemlerin tebliğinde evrak Ulusal Yargı Ağı Bilişim Sistemi (UYAP) üzerinden gönderildiği için kural olarak evrakın aslının elden verilmesi veya savcıya gösterilmesi gerekli değildir. Çünkü md. 38/A hükmü uyarınca, 2012 yllından itibaren her türlü ceza muhakemesi işlemlerinde UYAP’n kullanılması ve bu işlemlere ilişkin her türlü veri, bilgi, belge ve kararın, UYAP vasıtasıyla işlenmesi, kaydedilmesi ve saklanması kabul edilmiştir. Kanunlarda gösterilen istisnalar hariç olmak üzere, dosyalar güvenli elektronik imza kullanılarak UYAP’tan incelenebilmekte ve her türlü ceza muhakemesi işlemi yapılabilmektedir (md. 38/a, fik. 4)fik. 1-2). Güvenli elektronik imza ile imzalanan belge ve kararlar diğer kişi veya kurumlara elektronik ortamda gönderilir. Güvenli elektronik imza ile imzalanarak gönderilen belge veya kararlar, gerekmedikçe fiziki olarak ayrıca düzenlenmez ve ilgili kurum ve kişilere gönderilmez (md. 38/A, fik. 4). ${ }^{106}$

Güvenli elektronik imza ile imzalanan belge ve kararların diğer kişi ve kurumlara elektronik ortamda nasıl gönderileceği ise TK’ya, 11.01.2011 tarih ve 6099 sayılı Kanun ile eklenen ve 28.02.2018 tarih ve 7101 sayılı Kanun ile değiştirilen 7/a maddesi ile düzenlenmiştir. TK md. 7/a’da 7101 sayılı Kanun ile yapılan ve 01.10.2019 tarihinde yürürlüğe giren değişiklik ile, maddede sayılan gerçek ve tüzel kişilere tebligatın elektronik yolla yapılması zorunlu hale getirilmiştir. Elektronik yolla tebligatın yapılacağı kurumlar arasında adli ve idari yargı mercileri de açıcça sayılmıştır. ${ }^{107} \mathrm{CMK}$ md. 38/A’daki düzenlemeler ve TK md. 7/a’daki söz konusu zorunluluk sonucu artık hakim ve mahkeme

tebliğ edilmediği anlaşılmaktadır. Cumhuriyet Savcısına yapılacak tebligatın usulü 7201 Sayılı Tebligat Kanunu’nun $\underline{43}$. ve Tebligat Kanununun Uygulanmasına Dair Yönetmeliğin 65. maddesinde gösterilmiştir. Buna göre "Cumhuriyet Savcıllğına yapılacak tebligat tebliğ olunacak varaka aslının kendisine gösterilmesi suretiyle olur. Bu tebliğ bir mehile başlangıç olacaksa, Cumhuriyet Savcısı, gösterildiği günü varakanın aslına işaret ve imza eder." Tebligatın gösterilen usule göre yapılması geçerlilik koşuludur. Bu bakımdan Cumhuriyet Savcısina gösterilen usulde tebligat yapılması zorunludur. Bu şekilde yapılmayan tebligat usulsüzdür."

106 CMK md. 38/A fik. 11 uyarınca çıkartılan Bölge Adliye ve Adli Yargı İlk Derece Mahkemeleri ile Cumhuriyet Başsavcılıkları İdari ve Yazı İşleri Hizmetlerinin Yürütülmesine Dair Yönetmeliğin (Yazı İșleri Yönetmeliği) 5. maddesi de belge ve kararların elektronik ortamda düzenlenmesi ve ilgililere de elektronik ortamda gönderilmesi zorunluluğu getirmektedir. Söz konusu Yönetmelik md. 5/7 uyarınca, "Tutanak, belge ve kararlar elektronik ortamda düzenlenir ve gerekli olanlar ilgilileri tarafindan güvenli elektronik imza ile imzalanır. Elektronik ortamda düzenlenen ve güvenli elektronik imza ile imzalanan evrak UYAP kapsamındaki birimlere elektronik ortamda gönderilir. Ayrıca fizikî olarak gönderilmez."

107 06.12.2018 tarihinde yürürlüğe giren yeni Elektronik Tebligat Yönetmeliği elektronik ortamda yapılacak tebligata ilişkin usul ve esasları ayrıntılı olarak düzenlemiştir. Elektronik tebligatın nasıl yapılacağı da bu Yönetmeliğin 9 vd. maddelerinde düzenlenmiştir. Buna göre, tebligat çıkarmaya yetkili makam ve merci, elektronik tebligat mesajını hazırlayarak, Ulusal Elektronik Tebligat Sistemine (UETS) teslim edecektir. UETS, elektronik tebligat mesajinı zaman damgasıyla ilişkilendirerek muhatabın elektronik tebligat adresine ulaştıracaktır. Gizliliğin sağlanması amacıyla tebliğ edilecek içerik ve ekli dokümanlar, UETS tarafından şifrelenecek, ancak bunlar muhatap tarafından görülebilecektir. Elektronik yolla tebligat, muhatabın elektronik tebligat adresine ulaştığı tarihi izleyen beşinci günün sonunda yapılmış sayılacaktır (md. 9 fik. 1, 2, 3, 5). Elektronik tebligat adresine elektronik tebligat mesajı ulaştı̆̆ konusunda bilgilendirilmek isteyen muhatap, elektronik posta adresini veya kısa mesaj alma özelliği olan bir telefon numarasını PTT'ye bildirecektir. Elektronik tebligat, muhatabın adresine ulaştığı anda PTT tarafından muhataba bilgilendirme mesajı iletilecektir. Bu mesaj kısa mesaj alma özelliği olan telefona ücreti mukabilinde, elektronik posta adresine ise ücretsiz olarak iletilecektir. Ancak bu bilgilendirmelerin herhangi bir nedenle yapılamamış veya geç yapılmış olması, tebligatın geçerliliğini etkilemez (md. 10 fik. 1-2). Muhatap elektronik tebligat adresine, güvenli elektronik imzasını kullanarak veya e-Devlet kapısı üzerinden kimlik doğrulaması yaparak ya da PTT tarafından verilen şifre ile birlikte telefonuna kısa mesajla gelen tek kullanımlık doğrulama kodunu kullanarak erişebilecektir (md. 11). UETS, elektronik tebligatın muhatabın adresine ulaşıp ulaşmadığına dair delil kayıtlarını tutmak ve bu kayıtları, tebligat çıkarmaya yetkili makam ve mercie derhâl ve en geç yirmi dört saat içinde bildirmekle yükümlüdür (md. 12). 
kararlarının fiziki olarak Cumhuriyet başsavcılıklarına teslimini gerekli olmayıp, elektronik ortamda gönderilmesi gerekir. ${ }^{108}$

Kanaatimizce, CMK md. 38/A'daki düzenleme ve TK md. 7/a'daki zorunluluk karşısında bir kararın elektronik yolla gönderilmesi veya tebliği mümkün olduğu sürece CMK md. 38 hükmü uygulanmayacak ve tebliği gereken evrakın Cumhuriyet başsavcılığına verilmesi de söz konusu olmayacaktır. Ancak elektronik yolla gönderme veya tebligatın, zorunlu bir sebeple yapılamaması halinde (TK md. 7/a fik. 3, CMK md. 38/A, fik. 4) CMK md. 38 hükmü uyarınca evrakın aslının başsavcıllğa verilmesi suretiyle tebligatın yapılması ve tebliğ ile bir süre işlemeye başlıyorsa verildiği günün de evrakın aslına yazılması gerekir.

Hakim ve mahkeme kararlarının fiziki olarak Cumhuriyet başsavcılıklarına verilmeyip elektronik ortamda gönderilmesi gerektiği için elektronik ortamda gönderme de tebliğ olarak kabul edilecektir. Bunun sonucu olarak da CMK md. 38'de yer alan "Tebliğ ile bir süre işlemeye başliyorsa verildiği gün, Cumhuriyet Başsavcılığı tarafından evrakın aslına yazılır." hükmünün elektronik ortamda gönderilen evrak açısından uygulanması da söz konusu değildir. CMK md. 38/A fik. 9'da yer alan "Elektronik ortamda yapılan işlemlerde süre gün sonunda biter" hükmü ve Yazı İşleri Yönetmeliği md. 5/10'de yer alan "Elektronik ortamda yapılan işlemlerde süre gün sonunda biter. Elektronik ortamda yapılacak işlemlerin, ertesi güne sarkmaması açısından saat 00:00’a kadar yapılması zorunludur.” düzenlemesi nedeniyle de elektronik imza ile imzalanarak elektronik ortamda gönderilen bir karar Cumhuriyet savcısının UYAP ekranına düştüğü tarihte tebliğ edilmiş sayılacağını ve sürenin de CMK md. 39 uyarınca tebligatın yapıldığı günün ertesi günü başlayacağını kabul etmek gerekir. Yargıtay uygulaması da bu yöndedir. 8. CD’nin 15.10.2018 tarihli kararında; "Elektronik imza ile imzalanarak elektronik ortamda gönderilen kararlar yönünden Cumhuriyet Savcısının İstinaf kanun yoluna başvuru süresinin özel ve sonraki düzenleme olması sebebiyle CMK.nun 38/A maddesi gereğince kararın Cumhuriyet Savcısının UYAP ekranına düştüğü tarihte tebliğ edilmişs sayılacağından, CMK. nun 39/1. maddesi gereğince gün ile belirlenen süreler tebligatın yapıldiğının ertesi günü başlar, hükmü gereğince mahkeme dosyası ve hükmün Cumhuriyet Savcssının görüldü ekranina düştüğü tarihin ertesi günü başlayacağı" kabul edilmiştir.

Diğer taraftan elektronik yolla tebligatın ne zaman yapılmış sayılacağına ilişkin TK md. 7/a'da yer alan "Elektronik yolla tebligat, muhatabın elektronik adresine ulaştı̆̆ tarihi izleyen beşinci günün sonunda yapılmış sayılır." hükmü Cumhuriyet savcılarına elektronik ortamda gönderilen karar ve işlemler açısından uygulanmamalıdır. Çünkü yukarıda belirtildiği üzere, bir kararın elektronik ortamda Cumhuriyet savcisına göndermesi tebligat hükmünde olup, bu karar savcının UYAP ekranına düştügü tarihte tebliğ edilmiş sayılmalıdır. CMK md. 37/1 uyarınca, CMK md. 38/A hükmü, TK md. 7/a hükmü karşısında öncelikle uygulanması gereken özel hüküm niteliğindedir.

Diğer taraftan Cumhuriyet başsavcilığına elektronik ortamda gönderilmemiş ancak elektronik tebligat yoluyla tebliğ edilmiş olan kararlarda TK md.7/a fik. 5 hükmü uygulama alanı bulacaktır.

108 Dava dosyanın fiziki olarak Cumhuriyet Savcısına teslimine gerek olmadığı yönünde bkz. Yargıtay 8. CD, 15.10.2018.E 2018/6108 K 2018/10951. 
Bu durumda tebligatın başsavcılığın elektronik tebligat adresine ulaştığı tarihi izleyen beşinci günün sonunda yapılmış olduğu kabul edilmelidir. Ancak başsavcılığın elektronik tebligat içeriğini beş günlük süreden önce öğrenmesi durumunda süre işlemeye başlamaz. Çünkü kanun koyucu elektronik mesajın okunmasına tebligatın yapılması bakımından herhangi bir sonuç bağlanmamıştır. ${ }^{109} \mathrm{Bu}$ nedenle Cumhuriyet başsavcılığına elektronik yolla yapılan tebligatın yetkili savcı tarafından beş günlük süreden önce öğrenilmesi halinde de süre, tebligatın başsavcılığın elektronik adresine ulaştığı tarihi izleyen beşinci günün sona ermesinden sonra işlemeye başlayacaktır. ${ }^{110}$

\section{TEBLIGAT USULÜNE ILIŞKIN TK HÜKÜMLERi KARŞISINDA CMK HÜKÜMLERININ UYGULANABILIRLIĞi}

CMK md. 37/1'de, “Tebligat, bu Kanunda belirtilen özel hükümler saklı kalmak koşuluyla, ilgili kanunda belirtilen hükümlere göre yapılır." denilerek, tebligat usulü konusunda kural olarak TK hükümlerinin uygulanacağı belirtilmiştir. Yukarıda açıklandığı üzere CMK, esas itibariyle hakim ve mahkeme kararlarının ilgilisine bildirilmesine ilişkin temel ilkeleri düzenleyip tebligatın nasıl yapılacağını kural olarak özel bir kanun olan TK’ya bırakmıştır. Ancak yukarıda açıklanan serbest olmayan kişiye tebligat ile Cumhuriyet başsavcılığına tebligat ve CMK md. 37/2'deki yurt dişına tebligat ile ilgili hükümler de tebligat usulünü düzenlemektedir. Yine tanıkların ve bilirkişilerin çağrılmasında (CMK md. 43, 62) olduğu gibi bazı muhakeme işlemlerinin bildirilmesinde özel düzenlemelere yer verilmiştir. Elektronik tebligat açından CMK md. 38 karşısında CMK md. 38/A hükmü öncelikli uygulama kabiliyetine sahiptir.

Hakim ve mahkeme kararlarının tebligatı ile ilgili CMK ile TK hükümleri arasındaki farklılıklar açısından üzerinde durulması gereken bir başka husus CMK md. 37/2'de yer alan yurt dışına yapılacak tebligata ilişkin düzenlemedir. Söz konusu düzenlemeye göre, "Uluslararası antlaşmalar, yazılı belgelerin doğrudan doğruya postayla veya diğer iletişim araçlarıla gönderilmesini kabul ettiğinde; yurt dışına yapılan tebligat, iadeli taahhütlü posta veya diğer iletişim araçları ile gerçekleştirilir.” Bu düzenlemenin gerekçesi olarak madde gerekçesinde şu hususlar belirtilmiştir: “Tebligat Kanunu hükümlerine göre, yargılama işlemlerinin yabancı ülkede bulunan kişilere tebliği, çeşitli resmî makamlar aracıliğı ile gerçekleştirilmektedir. Bu, yargılamaların uzamasına neden olabilecek bir usuldür. Bu bakımdan Tasarıda getirilen düzenlemeyle ikili ya da çok taraflı uluslararası andlaşmaların öngörmesi hâlinde, ilgili yabancı ülkelere tebligatın doğrudan postayla veya diğer iletişim araçları ile yapılması kabul edilmiştir."

109 Levent Börü, 'Elektronik Tebligat' (2020) 10(1), Hacettepe Hukuk Fakültesi Dergisi, 183, 212.

110 Nitekim Yargitay Hukuk Genel Kurulu 14.01.2020 tarihli ve 2019/623 K - 2020/9 K sayılı kararında; “... 7201 sayıl Tebligat Kanunu'nun 7/a maddesinde muhatabın elektronik tebligatı tebellüğ etmiş sayılacağı tarihe ilişkin özel bir düzenleme yer almaktadır. Bu düzenlemeye göre Elektronik yolla tebligat, muhatabın elektronik adresine ulaştığı tarihi izleyen beşinci günün sonunda yapılmış sayılır. Bunun sonucu olarak elektronik tebligatta tebellüğ tarihi elektronik tebligatın muhatabın elektronik posta hesabına ulaştığı veya okunduğu tarih olmayıp tebligatın muhatabın elektronik adresine ulaştığ 1 tarihi izleyen beşinci günün sonu olmaktadır. Böylelikle, muhatabın kayıtlı elektronik posta hesabını kontrol etmemek suretiyle tebliğin sonuçlarını geciktirmesi ihtimali söz konusu olmayacaktır.”, diyerek bu yönde karar vermiştir. 
Yabancı ülkelerde bulunan muhataplara yapılacak tebligata ilişkin TK md. 25 ve md. 25/a’nın detaylı düzenlemesi karşısında CMK md. 37/2 hükmünün uygulama alanı bulup bulmayacağı üzerinde durulmalıdır. CMK ve TK’nın söz konusu hükümleri arasında farklılık veya çelişki bulunup bulunmadığını ortaya koymak için de önce TK'daki söz konusu hükümlere göre yurt dışına yapılacak tebligat usulünün ana hatlarını kısaca belirtmek gerekmektedir.

TK md. 25/1'e göre, "Yabancı memlekette tebliğ o memleketin salahiyetli makamı vasıtasiyle yapılır. Bunun için anlaşma veya o memleket kanunları müsait ise, o yerdeki Türkiye siyasi memuru veya konsolosu tebligat yapılmasını salahiyetli makamdan ister." Tebliğ olunacak evrak, tebligatı çıkaran merciin bağlı bulunduğu bakanlık vasıtasiyle Dışişleri Bakanlığına, oradan da görev gereği dikkate alınarak ilgili Türkiye büyükelçiliğine veya konsolosluğuna gönderilir. Dışişleri Bakanlığının aracılığına gerek görülmeyen hallerde tebligat evrakı, ilgili bakanlıkça doğrudan doğruya o yerdeki Türkiye büyükelçiliğine veya başkonsolosluğuna gönderilebilir.

TK md. 25/a uyarınca yabancı ülkede kendisine tebliğ yapılacak kimse Türk vatandaşı olduğu takdirde ise tebligatın yapılacağı ülke makamlarına başvurmadan doğrudan o yerdeki Türkiye Büyükelçiliği veya Konsolosluğu aracıllğıyla da tebligat yapılabilir. Bu halde Türk adli mercileri tarafından çıkarılacak tebligatta, tebliğ evrakı doğrudan o yerdeki Türkiye Büyükelçiliği veya Konsolosluğuna gönderilebilir.

TK’nın söz konusu hükümlerine göre, yabancı ülkelerde yapılacak tebligat evrakı tebligatın yapılacağı ülkedeki Türkiye elçiliği veya konsolosluğuna gönderilecek ve tebligatın yapılması da kural olarak o ülkenin yetkili makamı vasıtasıyla gerçekleştirilecektir. Türk elçilik veya konsolosluk görevlileri ise bu konuda aracılık yapacaktır. Ancak yabancı ülkede bulunan Türk vatandaşlarına o yerdeki elçilik veya konsolosluk görevlileri belli koşullara uyarak da doğrudan tebligat yapabilecektir. $\mathrm{Bu}$ durumda tebliği yapılacak evrak adli merciler tarafından doğrudan, ilgilinin bulunduğu yerdeki Türk büyükelçiliği veya başkonsolosluğuna gönderilebilecektir. Ancak Türkiye’nin taraf olduğu bazı sözleşmeler adli yardım taleplerinin Adalet Bakanlığı tarafından doğrudan talep edilen tarafın adalet bakanlığına yazılı olarak gönderilmesine de imkanı tanımaktadır. ${ }^{111}$

Görüldüğü üzere bir Türk mahkeme kararının yabancı ülkede bulunan muhatabına doğrudan posta veya elektronik yolla tebligatına TK md. 25 ve 25/a hükmü izin vermemektedir. Buna karşın CMK md. 37/2'ye göre ise uluslararası anlaşmalarca kabul edildiği takdirde tebligatın posta yoluyla (iadeli taahhütlü) veya diğer iletişim araçları ile, örneğin, elektronik tebligat yoluyla, yapılması gerekmektedir. Diğer bir ifade ile tebligatın yapılacağı muhatabın bulunduğu ülke ile Türkiye arasında doğrudan posta yoluyla tebligat yapma imkanının bulunması halinde bu usulün kullanılması, böyle bir imkanın bulunmaması halinde ise tebligatın TK md. 25 ve 25 a maddelerine göre yapılması gerekmektedir.

Türkiye tarafından 11.07.2016 tarihinde onaylanan 08.11.2001 tarihli Ceza İşlerinde Karşılıklı Yardım Avrupa Sözleşmesine İkinci Ek Protokolün 16. maddesi ile yabancı ülkede bulunan muhataba posta

111 Ceza İşlerinde Karşılıklı Yardım Avrupa Sözleşmesine İkinci Ek Protokol md. 4. 
yoluyla doğrudan tebligat yapılması kabul edilmiştir. Bu hükme göre, "Herhangi bir Tarafin yetkili adli makamları usule ilişkin belgeleri ve adli kararları posta yoluyla doğrudan diğer Tarafın ülkesindeki kişilere gönderebilir. Usule ilişkin belgeler ve adli kararlar, muhatabın raporda belirtilen makamdan bilgi alabileceğini söyleyen ve bu evrakların söz konusu kişinin hakları ve yükümlülüklerini belirten bir raporla birlikte sunulur. Yukarıda bahsedilen 15. maddenin 3. fikrasının hükümleri bu rapor için geçerli olur.” Protokolün bu hükmü karşısında Türk ceza mahkemesi kararlarının Protokole taraf olan bir ülkedeki muhataba tebliğ için posta yoluyla doğrudan gönderilmesi mümkündür.

Tebligatın yapılacağı ülkenin İkinci Ek Protokolü onaylamış olması veya Türkiye ile söz konusu ülke arasında posta ile tebligata imkan tanıyan bir sözleşmenin bulunması halinde, CMK md. 37/2 uyarınca tebligatın posta yoluyla yapılması gerekir. Yargıtay uygulamaları da bu yöndedir. CGK’nın 25.12.2018 tarihli bir kararında, ${ }^{112}$ "şikâyetçilerin yurt dışına çıkıp çıkmadıkları araştırılıp, yurt dışına çıktıklarının tespiti hâlinde CMK'nın 37. maddesinin ikinci fikrası gereğince Irak Cumhuriyeti ile Türkiye Cumhuriyeti arasında doğrudan doğruya posta yoluyla tebliğ yapma imkânının araştırılması, böyle bir imkânın bulunmaması durumunda ise 7201 sayıl Tebligat Kanunu'nun 25. maddesi gereğince gerekçeli kararın ilgili bakanlıklar aracılı̆̆ıla tebliğinin” sağlanması gerektiğini belirtilerek, CMK md. 37/2 hükmünün TK md. 25’e göre öncelikle uygulanması gerektiğine işaret etmiştir. Aynı doğrultudaki CGK'nın 05.11.2019 tarihli başka bir kararında113 da, "suçtan zarar görenin yurt dışına çıkıp çıkmadı̆̆ı araştırılıp yurt dışına çıktığının tespiti hâlinde CMK’nın 37. maddesinin ikinci fikrasi gereğince Gürcistan Cumhuriyeti ile Türkiye Cumhuriyeti arasında doğrudan doğruya posta yoluyla tebliğ yapma imkânının araştırılması, böyle bir imkânın bulunmaması durumunda ise 7201 Sayılı Tebligat Kanunu'nun 25. maddesi gereğince gerekçeli kararın ilgili bakanlıklar aracılı̆̆ıla tebliği sağlanarak yedi günlük temyiz süresinin başlatılması" gerektiğine karar verilmiştir. ${ }^{114}$

Belirtilen bu yasal düzenlemeler ve Yargıtay kararlarına rağmen halen yürürlükte olduğu anlaşılan Adalet Bakanlığı Uluslararası Hukuk ve Dış İlişkiler Genel Müdürlügüunün Cezai Konularda Uluslararası Tebligat adl 16.11.2011 tarih ve 69/3 nolu Genelgesi, TK md. 25 vd. hükümlerine göre hazırlanmış olup, yabancı ülkedeki muhataba doğrudan posta yoluyla tebligata izin veren bir düzenleme içermemektedir. Posta yoluyla tebligat yanında teknolojideki gelişmelere paralel olarak yabancı ülkede bulunan kişilere elektronik yolla tebligat usulünün de uygulamaya konmasında yarar bulunmaktadır. Nitekim yukarıda belirtilen 2 Nolu Ek Protokolün 4. maddesinin 9. fikrasına ${ }^{115}$ göre, adli yardım talepleri elektronik yolla talep edilen devlete iletilebilecektir. Diğer taraftan Cezai

112 CGK, 16.07.2021, E 2017/619 K 2018/674 (https://legalbank.net/belge/y-cgk-e-2017-619-k-2018674-t-25-12-2018/3360052).

113 E 2015/11-1080, K 2019/637.

114 Aynı yönde bkz. CGK, 28.05.2020, E 2020/6-98 K 2020/234: “CMK’nın 37. maddesinin ikinci fikrası gereğince İtalyan Cumhuriyeti ile Türkiye Cumhuriyeti arasında doğrudan doğruya posta yoluyla tebliğ yapma imkânının araştırılması, böyle bir imkânın bulunmaması durumunda ise 7201 Sayılı Tebligat Kanunu'nun 25. maddesi gereğince gerekçeli kararın ilgili bakanlıklar aracılı̆̆ıyla tebliği sağlanarak yedi günlük temyiz süresinin başlatılması ... ”

115 “Bu Sözleşménin veya Protokollerinin altında belirtilen herhangi başka muhaberatlar ve karşılıkl yardım talepleri, talep eden Tarafin talep üzerine herhangi bir zamanda orijinal metnin ve nüshanın yazıl bir kaydını tutmaya hazır olması şartıyla herhangi bir elektronik yolla veya uzaktan iletişim aracıyla iletilebilir. Ancak, herhangi bir Akit Taraf, Avrupa Konseyi Genel Sekreteri'ne herhangi bir zamanda gönderilen bir beyanname ile elektronik veya diğer uzaktan iletişim yolları aracılı̆̆ıla alınmış talepleri kabul etme ve yerine getirmeye razı olduğu durumları belirleyebilir." 
Konularda Uluslararası Adli İş Birliği Kanunu’nun Türk mercilerinin adli yardım taleplerinin yabancı ülkelere gönderilmesinde herhangi bir zorunlu usul öngörmeyen 7. maddesi hükmü de posta veya elektronik yolla adli yardım taleplerinin gönderilmesine engel teşkil etmemektedir. ${ }^{116}$ Söz konusu genelgenin posta yoluyla tebligat ile elektronik yolla tebligat da dikkate alınarak yeninden düzenlenmesinde yarar bulunmaktadır.

\section{SONUÇ}

Çalışmada ulaştı̆ıımı sonuçları şu şekilde özetleyebiliriz:

1. Anayasa ve kanunlarla güvence altına alınmış olan hak arama özgürlüğünün kullanılabilmesi için devlet işlemlerinin kişilere usulüne uygun olarak bildirilmesi gerekir. Hakim ve mahkeme kararların bildirilmesine ilişkin kanundaki düzenlemeler öncelikle, adil yargılanma hakkı kapsamında yer alan hukuki dinlenilme hakkının sağlanmasına ve güvence altına alınmasına hizmet etmektedir.

2. Md. 35 'in madde başlığı "kararların açıklanması ve tebliğı" adını taşımakla birlikte, maddenin düzenleniş yeri, md. 33 ve 34'ün konusu ve md. 35/2'nin ifade şekli dikkate alındığında savcılık kararlarının bildirilmesinin madde kapsamında düzenlenmediği anlaşılmaktadır. Kararların açıklanması veya tebliği suretiyle bildirileceği ilgili kişi kapsamına söz konusu karardan hakları veya hukuki statüleri etkilenecek her muhakeme katılanı dahildir. İlgili kişinin karardan dolayı zarar görmesi veya görecek olması gerekmez.

3. Kararların bildirileceği ilgili kişi için md. 35’te “ilgili taraf”tan söz edilmektedir. Madde metnindeki bu ifadeyi muhakemeye katılan ve verilen karardan hakları etkilenen ilgili kişiler ve savcllık olarak anlamak gerekir. Bu nedenle ilgili tarafı sadece kanun yoluna başvuru hakkı bulunanlarla sınırlı olarak anlamamak gerekir. Madde metninde "taraf" ifadesinin kullanılması da isabetli olmamıştır. Nitekim kaynak Alman CMK $\$ 35 / 1$ ’te de kararların “ilgili kişiye” bildirilmesinden söz edilmektedir. Mağdur ve suçtan zarar görenler de madde kapsamında ilgili kavramına dahildir. Bu nedenle verilen kararlardan etkilenen mağdur, şikayetçi veya suçtan zarar gören ve katılana da kararın bildirilmesi gerekir.

4. Md. 35/1'te yer alan "kararların açıklanmasından" maksat, verilen kararların hazır olan ilgilisine sözlü olarak bildirilmesi, yani duyurulmasıdır. Kararın açıklanacağı şüpheli veya sanık, meramını anlatabilecek derecede Türkçe bilmiyorsa açıklama, atanacak tercüman vasıtasıyla yapılmalıdır. AİHM içtihatlarına göre, sanığın adil yargılanma hakkından yararlanmasını güvence altına alacak ölçüde, kararlar da dahil olmak üzere, anlaması gereken bütün soruşturma ve kovuşturma işlemlerinin mahkeme dilini bilmeyen şüpheli veya sanığa tercüme edilmesi gerekir.

5. Önemi nedeniylekanun yolu başvuru hakkının bildirilmesi md. 231/1-4’te özel olarak düzenlemiştir. Kanun yolu başvuru hakkının bildirilmesine ilişkin md. 34/2 hükmünde "başvurulabilecek kanun

1166706 sayılı Kanun hakkında bilgi için bkz. Faruk Turhan, '6706 Sayılı Cezai Konularda Uluslararası Adli İş Birliği Kanunu’nun Kapsamı ve Genel Hükümleri Hakkında Bir Değerlendirme’, (2019) 21 (Prof. Dr. Durmuş Tezcan’a Armağan Özel Sayı), D.E.Ü. Hukuk Fakültesi Dergisi, 3067 vd. 
yolu, süresi, mercii ve şekilleri belirtilir” deniliyorsa da bu hükmün kaynak Alman CMK’da ( $\$ 35 \mathrm{a}$ ) olduğu gibi, kanun yolu başvuru hakkının öğretilmesi veya kanun yolu başvuru imkanları hakkında bilgilendirme şeklinde anlaşılması daha doğru olacaktır. Hak arama özgürlüğünün gerçekleştirilmesi için söz konusu olduğu için ilgili kişiye hangi kanun yoluna başvurabileceği konusunda anlayacağı şekilde bilgilendirme yapılmalıdır. Kanun yolu başvuru hakkı konusundaki bilgilendirmenin yapılmaması, eksik veya hatalı yapılması hükmün bozulması nedenidir.

6. TK md. 11'e göre, vekil ile takip edilen işlerde tebligat vekile yapılmalıdır. Yargıtaya göre, vekilin ceza muhakemesindeki karşıllğı olan müdafie yapılan tefhim veya tebligattan sonra ayrıca sanığa da tebligat yapılması gerekli olmayıp, gerekmediği halde yapılan tebligat temyiz süresini yeniden başlatmaz. Kanun yolu başvuru süresinin başlaması açısından Yargıtayın görüşü yerinde olmakla birlikte, sanığın yokluğunda ve müdafiin yüzüne karşı verilen kararın ayrıca sanığa tebliğ edilmeyeceğine ilişkin içtihadı yerinde değildir. Sanığa yapılacak tebligat, sanığın karar içeriği hakkında bilgi sahibi olması, karara karşı müdafiin kanun yolu başvurusu yapıp yapmadığını denetlemesi ve başvuru yapılmamış olması halinde eski hale getirme talebinde bulunmak için koşuları inceleme imkanı verecektir.

7. Muhakeme işlemlerinin bildirilmesi usullerinden biri de kararın tebliğidir. Md. 35/2'ye göre, bir hakim veya mahkeme kararının hazır bulunamayan ilgilisine tebliğ zorunluluğu için dört koşulun bulunması gerekmektedir. Bunlar; kararın, hakim veya mahkeme tarafından verilmiş bir karar olması, karara karşı kanun yoluna başvurulabilecek olması, kararın koruma tedbirlerine ilişkin olmaması ve kararın verildiği sırada ilgilinin hazır bulunamamış olmasıdır.

8. Kanun yolu başvuru hakkı bulunmasa da ilgilisi açısından herhangi bir hak veya yükümlülük doğuran savcılık işlem ve kararlarının da ilgilisine bildirilmesi hukuk devleti ve hukuki dinlenilme hakkının gereğidir.

9. Md. 35/2'in düzenlemesine göre tebliğ edilmesi gereken karar, aleyhine kanun yoluna başvurulabilecek bir hakim veya mahkeme kararı olmalıdır. Kanun yolundan neyin anlaşılması gerektiği ve hangi kararlara karşı kanun yoluna başvurulabileceği hususunun öncelikle CMK'ya göre belirlenmesi gerekir. Olağan kanun yolları yanında olağanüstü kanun yolları da md. 35/2 kapsamında değerlendirilmelidir. Bu nedenle kesin nitelikte olduğu için olağan kanun yolu başvuru imkanı bulunmayan ilk derece, bölge adliye mahkemesi ve Yargıtay kararları da hazır bulunmayan ilgilisine tebliğ edilmeli veya başka bir surette bildirilmelidir.

10. Md. $35 / 2$ 'de sadece aleyhine kanun yoluna başvurulabilecek olan kararların tebliğinin zorunlu kılınmış olması isabetli değildir. Hem adil yargılanma hakkının gereği hem de verilen karar ile elde edilecek hakkın veya uğranacak mahrumiyetin bilinmesi açısından her türlü mahkeme ve hakim kararlarının verildiği sırada hazır olmayan ilgilisine tebliğ veya başka bir şekilde bildirilmesi gerekir. CMK md. 35/2 hükmünün ilgilinin huzurunda verilmeyen bütün hakim ve mahkeme kararların ilgilisine bildirilmesi yönünde yeniden düzenlenmelidir. 
11. Temyiz kanun yoluna ilişkin bilgilendirme kapsamında, temyize ilişkin on beş günlük başvuru süresi yanında, CMK md. 295/1 uyarınca bölge adliye mahkemesinin gerekçeli kararının tebliğinden itibaren işlemeye başlayan yedi günlük süre içerisinde gerekçeli temyiz dilekçesinin verilmesi gerektiği konusunda da bilgilendirme yapılması gerekir. Bu yöndeki CGK ve ceza dairelerinin kararlarının isabetli olduğunu düşünüyor, aksi yöndeki CGK kararlarındaki görüşlere ise katılmıyoruz.

12. Md. 35/2'ye göre, niteliği itibariyle gizli olsun veya olmasın koruma tedbirlerine ilişkin hakim veya mahkeme kararları, kararın verilmesi sırasında hazır bulunmayan ilgilisine tebliğ edilmeyecektir. Ancak koruma tedbirlerine ilişkin de olsa yapılan işlemler ve verilen kararlardan etkilenenlerin kanun yollarına veya diğer hukuki çarelere başvurabilmeleri için bu kararların da usulüne uygun olarak ilgilisine bildirilmesi gerekir. Md. 35/2'de koruma tedbirlerine ilişkin bütün kararlar açısından tebliğ yasağı getirilmesi gerekli olmadığı gibi, infazı gerekmeyen kararlar açısından da isabetli değildir.

13. Md. 35/3'te serbest olmayan kişi veya tutukluya tebligata ilişkin özel bir düzenleme yapılmıştır. CMUK md. 33/2'de sadece tutukluya tebliğ edilen kararın okunup anlatılması kabul edilmişti. Yeni düzenlemede tutukluluk dışındaki başka sebeplerle özgürlüğü kısıtlanmış kişiler için de aynı usul kabul edilerek söz konusu boşluk giderilmiştir. Ancak tutuklu kişi de serbest olmayan kişi olduğu için madde metninde ayrıca tutuklu kişiden bahsedilmesine gerek bulunmamaktadır. Kararın, serbest olmayan veya tutuklu olan ilgilisinin yokluğunda verilmesi nedeniyle tebliği gereken durumlarda md. 35/3 uyarınca ayrıca ilgilisine okunup anlatılması zorunludur.

14. Kaynak Alman CMK $₫ 36 / 2$ 'de, duruşmada düzenin sağlanması ile ilgili kararların savcılığa verilmeyeceği belirtilerek, infazı gereken kararların savcılığa verilmesine ilişkin kurala bir istisna getirilmiştir. CMK md. 36/2'de infazı gereken kararların savcılığa verilmesi açısından herhangi bir istisnaya yer verilmemiş olsa da kaynak Alman kanununda olduğu gibi Türk hukukunda da duruşmanın düzen ve disiplini ile ilgili olarak hakim, mahkeme başkanı veya mahkemenin CMK md. 203-204 uyarınca almış olduğu tedbir ve kararların infazı ile ilgili hususların yerine getirilmesini sağlamanın da mahkemenin yetkisinde olduğunu kabul etmek gerekir.

15. CMK md. 38/A’daki düzenleme ve TK md. 7/a hükmündeki zorunluluk karşısında elektronik tebligat yapılması mümkün olduğu sürece CMK md. 38 hükmünü uygulanmayacak ve tebliği gereken evrakın başsavcılığa verilmesi de söz konusu olmayacaktır. Ancak elektronik yolla tebligatın, zorunlu bir sebeple yapılamaması halinde evrakın aslının başsavcılığa verilmesi suretiyle tebligatın yapılması gerekir.

16. Hakim ve mahkeme kararlarının elektronik ortamda Cumhuriyet başsavcılıklarına gönderilmesi tebligat olarak kabul edilmelidir. Elektronik imza ile imzalanarak elektronik ortamda gönderilen bir karar Cumhuriyet savcısının UYAP ekranına düştüğ̈̈ tarihte tebliğ edilmiş sayılmalı ve sürenin de tebligatın yapıldığı günün ertesi günü başlayacağı kabul edilmelidir. Aksi yönde bazı kararları olmakla birlikte Yargıtay uygulaması da bu yöndedir. 
17. Türk mahkeme kararlarının yabancı ülkede bulunan muhatabına doğrudan posta veya elektronik yolla tebligatına TK md. 25 ve 25/a hükmü izin vermemektedir. Buna karşın CMK md. 37/2'ye göre ise uluslararası anlaşmalarca kabul edildiği takdirde tebligatın posta yoluyla (iadeli taahhütlü) veya diğer iletişim araçları ile, örneğin, elektronik tebligat yoluyla, yapılması gerekmektedir. Tebligatın yapılacağı ülkenin İkinci Ek Protokolü onaylamış olması veya Türkiye ile söz konusu ülke arasında posta veya diğer araçlarla tebligata imkan tanıyan bir sözleşmenin bulunması halinde, CMK md. $37 / 2$ uyarınca tebligatın posta veya diğer araçlarla yoluyla yapılması gerekir.

\section{KAYNAKLAR}

Artuç M, Açıklamalı Pratik Ceza Muhakemesi Kanunu (3. Bası, Ankara 2019).

Baytaz AB, Ceza Muhakemesi Hukukunda Sanığın Hukuki Dinlenilme Hakkı (İstanbul 2021)

Bıçak V, Ceza Muhakemesi Hukuku (4. Bası, Ankara 2018).

Börü L, 'Elektronik Tebligat', Hacettepe Hukuk Fakültesi Dergisi (2020), 10(1) 183-225.

Centel N ve Zafer H, Ceza Muhakemesi Hukuku (19. Bas1, İstanbul 2020)

Gökcen, Ahmet, Balcı, M ve Alşahin, ME ve Çakır, K, Ceza Muhakemesi Hukuku (5. Baskı, Ankara 2021).

Demirağ F, Örneklerle Ceza Muhakemesi Hukuku İşlemleri ve Adli Yazışmalar (2. Bası, Ankara 2020).

Keskin S, 'Ceza Muhakemesinde Müdafie Yapılan Tebligat Sanığa Yapılmış Sayılır Mı?', İstanbul Hukuk Fakültesi Mecmuası (İHFM) (LV), 3 (1997) 355-362.

Kılıç AŞ, “Tercümandan Faydalanma Hakkı Çerçevesinde Sanığın Seçtiği Dilde Savunma Yapması Üzerine Bir Değerlendirme”, Ankara Üniversitesi Hukuk Fakültesi Dergisi (2016), 65 (4) 2101-2131.

Kunter N, Yenisey F ve Nuhoğlu A, Ceza Muhakemesi Hukuku (15. Bası, İstanbul 2006).

Larcher H, StPO in: , in: Jürgen Graf (ed), BeckOK StPO mit RiStBV und MiStra, Herasugegeben Jürgen Graf (39. Edition, Stand: 01.01.2021).

Maul H, StPO in: Rolf Hannich (Ed) Karlsruher Kommentar zur Strafprozessordnung mti GVG, EGGVG und EMRK (8. Bas1 2019)

Meyer-Gossner L, Strafprozessordnung mit GVG und Nebengesetzen (56. Bas1, 2013).

Okuyucu Ergün G, Ceza Muhakemesi İșlemleri (Ankara 2015).

Öncü M, 'AİHS’nin $6 \$ 3$ e) Hükmü Anlamında Tercüman Yardımından Yararlanma Hakkı', Dokuz Eylül Üniversitesi Hukuk Fakültesi Dergisi (2014) 16(Özel Sayı, Prof. Dr. Hakan PEKCANITEZ’e Armağan) 4457-4495.

Özbek VÖ, Doğan K ve Bacaksız P, Ceza Muhakemesi Hukuku (13. Bask1, Ankara 2020).

Öztürk B, Tezcan D, Erdem MR, Sırma Gezer Ö, Saygılar Kırıt YF, Alan Akcan E, Özaydın Ö, Erden Tütüncü E, Altınok Villemin D, Tok MC, Nazari ve Uygulamal Ceza Muhakemesi Hukuku (13. Bas1, Ankara 2019).

Özen M, Ceza Muhakemesi Hukuku Dersleri (3. Bası, Ankara 2018).

Şahin C ve Göktürk N, Ceza Muhakemesi Hukuku II (11. Bası, Ankara 2021).

Şahin C, Ceza Muhakemesi Kanunu Gazi Şerhi (Ankara 2005).

Şık H, Türk Adli Yargı Sisteminde Savcıllk Kurumu (Ankara 2018).

Toroslu N ve Feyzioğlu M, Ceza Muhakemesi Hukuku (20. Bas1, Ankara 2020).

Tulay, ME, 'Seri Muhakeme Usulü (CMK m. 250)', (2020) (2), İzmir Barosu Dergisi 117-157.

Turhan F, 'Ceza Muhakemesinde Sürelerin Kusur Olmaksızın Geçirilmesinde Eski Hale Getirme’, Dr. Silvia Tellenbach’a Armağan (Ankara 2018) 1227 - 1268. 
Turhan F, ‘6706 Sayılı Cezai Konularda Uluslararası Adli İş Birliği Kanunu’nun Kapsamı ve Genel Hükümleri Hakkında Bir Değerlendirme', (2019) 21 (Prof. Dr. Durmuş Tezcan’a Armağan Özel Sayı), D.E.Ü. Hukuk Fakültesi Dergisi 3067-3109.

Ünver Y ve Hakeri H, Ceza Muhakemesi Hukuku (17. Bask1, Ankara 2020).

Valerius B, StPO, in: Hans Kudlich (Ed), Münchener Kommentar zur Strafprozessordnung, StPO, Cilt 1: $₫ \$$ 1-150 (1. Bas1, 2014)

Wesslau E, StPO in: Jürgen Wolter (Ed), SK-StPO, Systematischer Kommentar zur Strafprozessordnung mit GVG und EMRK Cilt I, \$\$1-93 (4. Bası 2013).

Yenisey F ve Nuhoğlu A, Ceza Muhakemesi Hukuku (7. Bası, Ankara 2019).

Yenisey F ve Oktar S, Alman Ceza Muhakemesi Kanunu/Strafprozessordnung (StPO) (2. Bası, İstanbul 2015). 